\title{
Lapurdum
}

LAPURDUM Euskal ikerketen aldizkaria | Revue d'études basques |

Revista de estudios vascos | Basque studies review

$9 \mid 2004$

Numéro IX

\section{XVIII. mendeko autore ezezagun bat}

\section{Koro Segurola}

URL : http://journals.openedition.org/lapurdum/879

DOI : 10.4000/lapurdum.879

ISSN : 1965-0655

Éditeur

IKER

Édition imprimée

Date de publication : 1 novembre 2004

Pagination : 243-282

ISBN : 2-68781-376-X

ISSN : $1273-3830$

\section{Référence électronique}

Koro Segurola, «XVIII. mendeko autore ezezagun bat », Lapurdum [Linean], 9 | 2004, Sarean emana---an 01 mars 2009, kontsultatu 01 mai 2019. URL : http://journals.openedition.org/lapurdum/879 ; DOI 10.4000/lapurdum.879 


\title{
XVIII. mendeko autore ezezagun bat
}

\author{
Koro SEGUROLA \\ Deustuko Unibertsitateko Doktoregaia \\ Euskaltzaindia (EHHA)
}

\section{Sarrera}

Izenburua bera ikerlan zabal baten emaitza dugu eta oraindaino ezagutzen ez genuen XVIII. mendeko autore baten aurrean jartzen gaitu. Gure ibilbidearen hasieran, ordea, mende horretako idazle ezagun batekin aurkitu ginen eta ondoko ikerketaren ondorioa dugu gaurko aurkezpen labur hau. Bidean nondik norako urratsak eman ditugun erakusten saiatuko gara hemen, modu laburrean, baina has gaitezen gure abiapuntuaren berri ematen.

Duela zenbait urte, Loiolako jesuiten ikastetxean mendeetan ilunpean egon ziren bederatzi eskuizkribu heldu ziren gure eskuetara gutun-azal baten barruan. Gutunazalaren $(25 \times 19 \mathrm{zm})$ gainean hitz hauek irakurtzen ditugu :

SERMOIAK (Esku-iskribuak) Adviento. Aginduak. Giltzapean. Frantzisko Xavierren bederatziurrena. Aita Larramendi-renak?

Honela bada, ustez Larramendik idatzitako sermoiak ditugu esku artean. Era berean, Loiolako liburutegiko armairu berezi batean (giltzapean) egon direla ere jakiten dugu. Eskuizkribuak paper baten barruan bilduta daude eta bertan bi eskutako hitzak ageri dira :

\section{Sermones euskaros del siglo 18. Parecen de letra del P. Larramendi ??}

[Behean :] Hau I. Ara naren letra da. Goiko Iñaki. Tellechea Idigora sek esan zidan letra hori Larramendirena zela ematen zuela. Goikoetxea Iñaki.

Hemendik berri hauek jasotzen ditugu :

1. Goiko hitzak Aita Aranarenak dira, Aita Iñaki Goikoetxearen ${ }^{1}$ ustez, eta azpikoak bereak, Aita Goikoetxearenak, alegia.

2. Aita Aranaren ustez XVIII. mendeko sermoiak dira eta Aita Larramendik idatziak, baina honetan ez dago ziur.

3. Aita Goikoetxeak Aita Telletxea Idigorasen iritzia jaso du eta Aita Aranarekin bat dator, Larramendiren letra dela iruditzen baitzaio Aita Telletxeari ere.

Eskuizkribu sorta biltzen duen papera XIX. mendekoa da, paperaren ur markak papera garai horretan ekoitzi zela adierazten baitu. ${ }^{2}$

Hauek izan ziren kanpotik edo azaletik jaso genituen berriak. Esanak esan, ordea, eskuizkribu hauek datatu eta izenpetu gabe daude. Honen garrantziaz jabeturik eta

1 - Iñaki Goikoetxea Loiolako Euskal Liburutegiko arduraduna zen.

2 - Papera eta ur markak guk aztertu ditugu. Gai honen inguruko azalpenak ASJUren hurrengo alean argitaratzekotan den gure beste lan batean biltzen dira : "Paperaren ur markak". 
zuhurtasunez jokatu nahian bi datu horiek, garaia eta egilea, egiaztatu genituen. Horrezaz gain, eta ondorioak zehaztearen alde, bi emaitzak erkatzea ere derrigorrezkoa zen. Badira urte batzuk zeregin hauetatik abiatu ginela eta helmugara iritsi ez bagara ere, aurkezpen honek horren lekukotasuna jasotzeaz gain gure susmoa eta han hemenka aireatu ziren usteak ${ }^{3}$ argitu nahi ditu : Aita Larramendirenak ote dira Loiolako eskuizkribu hauek?

Hona hemen eskuizkribuetako lehen orrialdean jasotzen diren gaiak : 1. Segunda Funcion de la Quaresma ; 2. Quarta Funcion de la Quaresma ; 3. De la caridad o de la gracia ; 4. Infernuaz; 5. Circumcisión-circuncideretur; 6. S.F. Xavierren bederatziurrena ; 7. Adviento ; 8. Platicas p. la novena de S. F. Xavier ; 9. Pla ticas p. la novena de S. F. Xavier. Eskuizkribuak guk zenbatu ditugu, lan honetan zehar zenbakien bidez adieraziko baititugu.

Lehenengo hirurak oso txukun taxutuak daude baina zuzenketa ugari dago eta gehienak beste esku batek eginak dira, bi eskutako letra nabari baita. Lehen orrialdean, $\mathrm{R}$ bat dakusagu hiru hauetan ( $i$ Revisado ?). J. M. Lekuonak eman zigun iritzia gurea eginik, seguru asko argitaratzea zen egilearen asmoa baina utz dezagun orain kontu hau horretan. Laugarren eta seigarren eskuizkribuen gaiak ez ditu egileak idatzi Aita Aranak baizik, eskuizkribu guztiak bilduta zeuden orrian ere letra bera ageri baita. Arkatzez idatzita daude eta laugarrenean, gainera, A Larramendi ? irakurtzen dugu.

Tesi gaiaren aurrerapen bat izan daitekeen honetan alor batean mugatu dugu gaurko aurkezpena. Hori dela eta, Larramendi ez dela eskuizkribu hauen egilea frogatzen saiatuko gara, idatziak idatzi eta esanak esan. Gure lehenengo susmoa sendotu zen letraren arabera testuak konparatuaz eta, batez ere, hizkuntzaren aldetik mihatuaz, ondorio berera iritsi baiginen, ondoko orriotan erakusten saiatuko garen gisan. Beste esku bat ere ageri dela aipatu dugu eta A Aranak eta besteek Larramendiren izena aipatu izanaren zergatia aurkezpena amaitu baino lehen garbi geratuko dela uste dugu. Esku honek egin dituen aldaketen berri emango dugu eta hauetan oinarrituko gara gure gaurko asmora heltzeko. Aztergaitzat lehenengo lau eskuizkibuak hartu ditugu baina, batez ere, zuzenketa gehien dituzten lehen hirurak. Bestalde, gaineratu behar dugu eskuizkribu hauen papera ere aztertu dugula, paperaren ezaugarririk garrantzitsuena den ur marka, alegia, lehen mailako baliabide kronologikoa baitugu paper horretan idatzitako testua noizkoa den jakitera iristeko. Ikerketa honen ondorioz, azterketa zehatza ez baitugu orain azalduko, lehenengo sei eskuizkribuak 1742 baino lehenagokoak dira, zazpigarrena 1742 ondorengoa, hots, gutxienez urte horretan idatzia, ez lehenago, eta azken biak 1747 ondokoak baina aurreratu dezakegu, orain frogatzea luze joko bailiguke, 1750 baino lehenagokoak direla, hau da, ez dira 1750 ondotik idatziak. Beraz, guztiak XVIII. mendearen lehen erdialdekoak dira. Honek gutun-azalean eskainitako datua egiaztatzen digu eta azterketa honetatik bildu dugun emaitzarekin ere bat datorrela ikusiko dugu.

3 - Patxi Altunak eta Joseba Lakarrak 1990ean prestatu zuten Manuel Larramendi : Euskal Testuak liburuaren sarreran, honela esaten da: "Azken orduko oharra : Testuan esana bermatzera datorren berri pozgarria izan dugu, Patxi Altunak jakin duenez Larramendirenak izan daitezkeen beste bost sermoi agertu berri bait dira ; liburu honen argitalpena oso aurreratua izaki hemen ematerik ez badugu ere, aurki bide dituzte eskumenean irakurleak Larramendiren euskarazko idazkien multzoa hainbatez gehitzen duten hauek". Gerora honela zioen P. Altuna jaunak Manuel Larramendi. Hirugarren Mendeurrena (1690-1990), 1992, liburuan : "Hiru [sermoi] heldu dira guregana (ez baitirudi oraintsu Loiolan agertu omen diren berriak Larramendirenak direnik, ez diet bederen harenen eiterik ikusten)". Beranduago heldu ziren nire eskuetara eta kopurua bat ez badator ere P. Altuna jaunarekin hitz egin nuenean sorta honetaz ari zela, hain zuzen, jakinarazi zidan. Bihoazkio hemendik Aita P. Altuna jaunari nire eskerrik beroenak. J. Lakarra irakasleari ere benetan eskertu nahi nioke eskuizkribu hauek direla eta, egin dizkiodan galderei erantzuteko hartu astia eta agertu interesa. 
Azterketaren muinean sartu aurretik, hala ere, letra bera erakutsiko dugu, hau da, eskuizkribuan ageri diren bi eskuak Larramendiren beste eskuizkribu baten parean jarriko ditugu.

\section{Letra}

Lehenik, idazleak letra argia eta irakurterraza duela adierazi behar dugu. Alde horretatik ez digu neke eta ardaila handirik sortu eskuizkribuen irakurketak. Ez da harritzeko, ordea, hitzen batzuk duda-mudazko gertatzea edota idazleari berari oharkabean hutsegiteren bat itzurtzea ; ez eta paper hauek hiru mendeetan hainbat leku edota eskutatik pasa ondoren zenbait tokitan urratuta edo hondatuta egotea ere. Besterik da, hitzak lumatik paperera jalki zitzaiozkion tankera, bigarren aldiz irakurri zituenean zenbait aldetatik arras gogobeteko ez gertatu eta lehenaren grafia, nahiz hitzen forma, nahiz perpausen taxua biziki aldatu izana, orrialde batzuk ezabaketaz, aldakuntzaz eta zuzenketaz zikindurik eta marrasturik utziz. Sarreran adierazi dugunez, zuzenketa guztiak ez dira egileak berak eginak beste letra molde bat ez ezik bestelako aldaketa motak baitaude, gero azalduko dugun gisan. Gauza bat dago garbi, halere, egileari bat batean, berez, inoren eta ezeren eraginik eta gauzak bi bider pentsatu gabe isuri eta jalki zitzaiona azpiko testua dela, hau da, jatorragoa eta berezkoagoa. Hori dela bide, azpiko testu eta formak oinarritzat hartu ditugu edizioa prestatzerakoan. Bestalde, letraren kontu honetarako grafologiaren bidea ere urratu dugula esan behar dugu eta bere garaian zehatzago azalduko dugun arren, hortik jasotako emaitza eta gure azterketatik bildu duguna bat datozela adierazi nahi dugu.

Jarraian erakusten dugun argazkiaren goiko aldean Larramendiren Azkoitiko Sermoia ren zati bat ikus daiteke eta behean eskuizkribu hauetako beste bat.

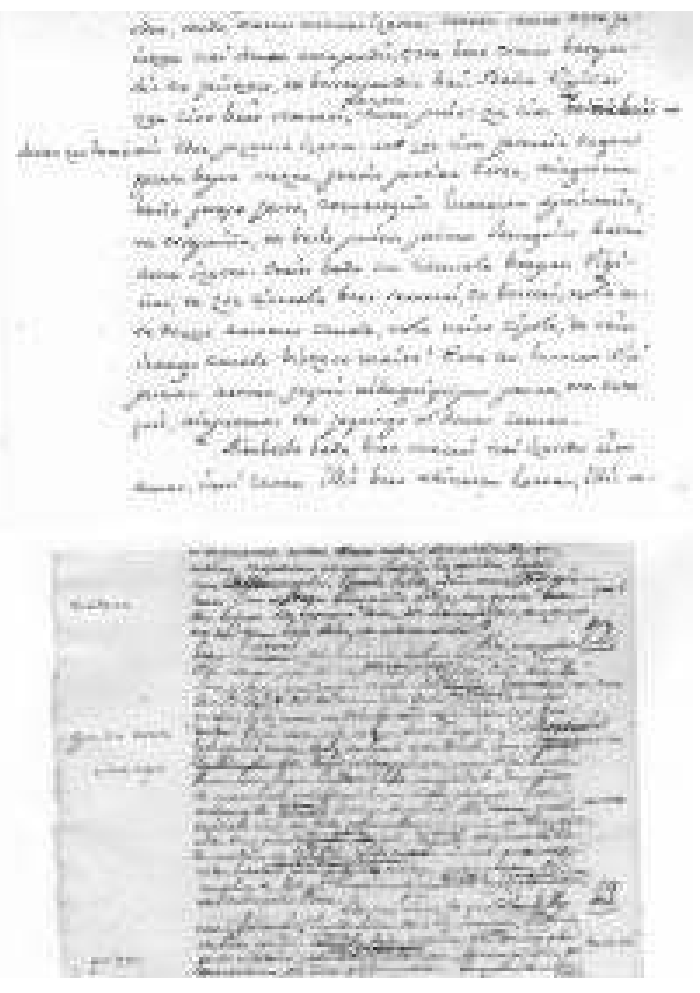


Guretzat ez da dudarik goiko eta beheko zatietako letrak ezberdinak direla, halaber, beheko testuan eta honen ertzetan ageri direnak ere ez dira traza berekoak. Haatik, beheko zatiko ertzetan ageri diren letrak goikoaren parekoak dira. Aita Telletxea Idigorasek egun batez beheko testuko letra Larramendirena zela esan zuen arren, urte batzuk geroago guri aurrez aurre ezeztatu egin zigun. Hizketaldi interesgarria bezain atsegina izan ondoren, eskuizkribuen aurrean jarri eta hartu beharreko denbora hartuta letraren arabera testua ez zela Larramendiren eskutik ilkia adierazi zigun. Bai, ordea, albotako zenbait ohar, hau da, Larramendiren eskua albotako zenbait oharretan garbi ikusten zuela ziurtasun osoz erantzun zigun. Areago, Larramendik idatzitako eskuizkibu bat aurrean jarri genioenean dardararik eta zalantza izpirik gabe orriz orri joan zen honen hitz eta esaldiak markatzen. Egun hartan Loiolan bestelakorik esan bazuen, presaren eraginez edo gainbegirada azkar baten ondorioz izango zela aitortu zigun. Horretan ez nuen eta ez dut inolako zalantzarik, norbaitek Larramendiren eskuizkribuak eskuetan eduki eta aztertu baditu, besteak beste, hori Aita Telletxea Idigoras baitugu.

\section{Hizkuntza}

Alderdi honetatik, gure abiapuntua edo oinarria eskuizkribuetan ageri diren zuzenketak izan dira, testugileak nahiz beste esku batek eginak. Zuzenketak hiru ataletan banatu ditugu : grafia, morfologia eta lexikoa. Oraingo gure helburua aipatu ditugun eskuizkribuen egilea Larramendi ez dela soilik frogatzea denez, ez gara hemen garaiko beste idazlan batzuekin erkaketa sakonetan sartuko.

\subsection{Grafia}

Zuzentzaileak ez du grafia mailan aldaketa handirik egiten, jarraian biltzen ditugunak maiz formari zein lexikoari begira eginak baitira. Alabaina, atal honetan ere jaso egin ditugu testugileak eta zuzentzaileak grafia sistema ezberdina darabiltela argiago edo zehatzago frogatzeko asmoz. Kontuan har, bestalde, aurkezpen honetan ez ditugula eskuizkribu guztiak aztergai, lehen aipaturikoak soilik baizik.

Egilearen hitzak $A$ letraz izendatu ditugu eta zuzentzailearentzat $B$ letra erabili dugu. Sermoigilea bera denean aldaketaren egilea, ez dugu letrarik ipini. Ondoan agertzen den parentesi arteko zifrak eskuizkribua adierazten du eta besterik adierazten ez denean, behin egindako aldaketa dela ulertu behar da. Testuetan diren beste agerraldiak adierazteko garaian ere berdin jokatu dugu, batez ere, garai ezberdinetako eskuizkribuak direlako.

2.1.1. TZ. $\left\langle\mathrm{c}^{(\mathrm{e}, \mathrm{i})}>/<\mathrm{Z}><\mathrm{tz}>\right.$

gorpucera A: gorputzari B (2) prometicen A: aguintzen B (1) iz A : hitz B (1)

Lehenengo bi aldaketak, irakurlea dagoeneko ohartu denez, ez dira zuzenzuzenean grafiari begira eginak zuzentzaileak beste nonbait baitzuen arreta jarria. Hala ere, adibidetzat hartu ditugu grafia honen erabilerak egilea ezagutzeko duen garrantzia nabarmendu nahirik. Hirugarren zuzenketa beste sail batean ere aztertuko dugu, $<\mathrm{h}\rangle$ aren erabileran, hain zuzen ere. Honela, A-ren $\left\langle\mathrm{c}^{\mathrm{e}}\right\rangle$ eta $<\mathrm{z}>$ ren aldean zuzentzaileak $<\mathrm{tz}>$ idazten $\mathrm{du}$; halaber, ondotik ikusiko ditugun 
beste aldaketetan ere : aitzakia (birritan), autatzeko, egoitza, guertatzen, centzunaz, centzunez, ciricatzen.

Ikus dezagun A-ren idazkeran, ordea, salbuespenak diren edota beste testuinguruetan ere jokaera bera duen.

Goiko agerraldietan ez eze hurrengoetan ere $\langle\mathrm{c}>$ darabil $e$ eta $i$-ren aurrean :

abiacen $(1,3)$, a itacea $(1,2)$, a labacea $(2,6)$, a menazacen (1), apurcen $(2)$, batucen $(1,3)$, berriztucea (3), bicicen (2), bicicera (4), bildurceco (2), billacen (2), ca stiga cea $(1,2,3)$, comparacen $(2)$, condenacen $(4)$, deicen $(1,3)$, erasocen (1), eroicen (1), erregucen $(2,3)$, galdecen $(2,3,4)$, gorpuceco (2), guruce (1), izentacea (2), ondacea $(1,3)$, sendacen $(1)$ eta $b^{4}$

Badira salbuespenak eta hauetan $<\mathrm{z}>$ nahiz $<\mathrm{zz}>$ ageri dira :

azzean (1, hiru aldiz), guruze (1), deizen (1), poztuzen (2), zarze (2), zulazen (1), uzi $(1,2)$, uziceco $(2)$, uzizea $(1,2)$, uzzi $(1,2)$, uzzicen, uzzico (2). ${ }^{5}$

Beste testuinguruetan $\langle\mathrm{z}\rangle$ erabiltzen $\mathrm{du}$ :

aitazat (2), biziza $(1,2,3,4)$, gorpuz $(1,2,3){ }^{6}$ gorpuza $(1,3)$, gorpuzaren $(2,3)$, ozari (1), ${ }^{7}$ pagazalle (1), semezat (2), sustraizat, vizizan (2) etab. Baina < zz> ere ageri da : derizzo (1), izza (2).

Egileak berak ere egin ditu zuzenketa pare bat testuinguru honetan, bioz : biotz aldatu du hirugarren eskuizkribuan. Lehenengo lau eskuizkribuetan bioz da nagusi eta besteetan, batez ere 8.ean eta 9.ean, biotz. ${ }^{8}$

$<\mathrm{n}>$ ondotik ere, salbuespen batzuk gorabehera, $<\mathrm{c}>$ idazten du $e$ eta $i$-ren aurrean :

aguince (2), apaincen (2), bea rguincetan (2), biguncen (3), efincen $(1,2)$, esconcea $(2,3)$, intencio $(1,2)$, janciarequin $(2)$, penitenciaren $(2)$, quenceco (1), sucencen (3). Salbuespenak : anzic (2), janzi (1), onzi (3).

Beste testuinguruetan $(a, o$, eta $u$ bokalen aurrean $)<\mathrm{z}>$ :

anza (1), enzun $(1,2,3)$, eranzun $(1,2,3)$, esconza (2), semeenzat (1), zenzun (2), zenzunetic (1), zinzo (3) etab. ${ }^{9}$

$<\mathrm{r}>$ ondotik $<\mathrm{z}>$ nahiz $<\mathrm{c}>$ :

esquerzat (3), zorzigarren (1) apurcen (2), bildurceco (2) etab.

Bestalde, $<\mathrm{z} / \mathrm{sc}>$ ere ageri da : aserrazcen (1, "haserrarazten"), aberascen (8), sinisceco (9), siniscen (1), ${ }^{10}$ baina : iracasten (1), icasten (2), irabazten (1), icusten $(1,2) .{ }^{11}$ Zegamako dotrinan ere siniscen (2) eta siniztcen (45) irakurtzen dugu (Nic

4 - 8. eta 9. eskuizkibuetan bada <tz> : deitzen, oñatzeta ra, eriotza, bizitza etab. baina sarreran esan bezala, idazlan hauek beranduagokoak dira, gutxienez 1747koak. Eskuizkribu horietan, ordea, badira honelakoak ere : aconsejacen, a plicacen, asecen, berocen, billacen, biziceco, bizicea, bazuec, bazuei, comparacen, eranzun, enzuten, erregucen, sendacen etab. Paperaren eta ur markaren inguruan ik. 2. oharra.

5 - Birritan ondoko zuzenketa hau egiten du A-k bigarren eskuizkribuan : uchim $u z z i, u z i$.

6 - 8. eta 9. eskuizkribuetan gorputz idatzi du (cf. 4).

7-9. eskuizkribuan otzac ageri da, baina bada biziza ere.

8 - Ez da inon, halere, bihotz ageri.

9 - Hemen ere 9. sermoian untza dugu. Badira, hala ere, honela idatziak : eranzun, onzi, penitencia etab. 10 - Birritan idatzi du sinizcen eta lehen agerraldia soilik zuzendu du : siniscen. Ik. $<\mathrm{s} / \mathrm{<}>$ dela eta, siniztuco ere. 11 - Ohar bedi aurrekoen partizipioa -tu dela (sinistu, a serra tu, "aberastu"), baina baditu a sicen eta uzzizen ere. Aditz izena, izan ere, maiz partizipiotik sortzen du, morfologia atalean ere ikus daitekeen gisan (-n /-1 /-r) : quenducen, salducen, sortucen, artucen etab. Baina ez du a serratucen esaten, a serracen baizik. 
siniscen det; beragan siniztcen degula). Otxoa Arinen dotrinan (1713) eta Arzadunarenean ere (1758ko edizioan) $\langle\mathrm{zc}\rangle$ ageri da, alabaina, gaurko $t z$ erabileran : juntazcen (OA 16. or.), ${ }^{12}$ juntazcen, edo arrimatcen dio. Arzadunen 1758ko edizioan irakurtzen dugun gorpuzceraco (39.or.), ordea, akatsa izan daiteke, 1731 ko lehen edizioan ${ }^{13}$ gopuceraco (34. or.) ageri baita.

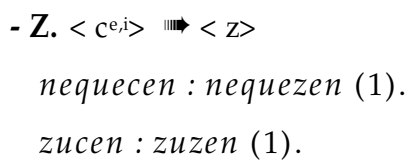

Aldaketa bakarrak dira eta A-k berak eginak lehen eskuizkribuan. Testuinguru horretan, $e$ eta $i$ aurrean, hitz bera $<\mathrm{z}>$ nahiz $<\mathrm{c}>\mathrm{z}$ idatzita ere agertzen da, zenbaitetan, gainera, sermoi berean :

baicic $(1,2,3) /$ baizic $(1,2,3,4)$; bicija (3) / bizia $(1,3)$; biziric $(4)$; ceben $(1,3) /$ zeben $(1,2,3)$; cergatic $(1,2,3)$ / zergatic $(1,2,3)$; ceru, ceruco $(2,3)$ / zerua, zeruetan $(3,1)$; cituzten $(2,3)$ / zituzten $(1,2)$; edocein $(1,2,3)$ / edozeinetan (1) ; lendabicico $(1,2,3) /$ lendabizico $(1,2,3)$; luce $(1,2) /$ luze $(2)$, etab. Baina beti : gracia, madaricacioa, mereci, preciatua, salvacioa .

Salbuespen gisa guzzia (-ac, -ai...) hitza ageri da lehen bi eskuizkribuetan eta guztia ere erabiltzen duen arren, $<\mathrm{zz}><\mathrm{z}>$ (guzia) baino gehiagotan idazten du.

12 - Dodgsonen edizioan, berriz, juntatcen ageri da (18. or.).

13 - Doctrina Christianeen Explica cinoa, Vitoriaco Ciudadean, 1731. Urte honetako facsimilea erabili dugu, baina $1758 \mathrm{koa}$ ere aurrean izan dugu (Iruñean). 1731 koak 56 orri ditu eta dotrina 13. orrian hasten da. $1758 \mathrm{koak}$, berriz, 7 orri gehiago ditu eta dotrina 17.ean hasten da. Konparaketa azkar bat eginez aldaketa batzuk ageri dira baina maila ezberdinetakoak, noski : ofrecietandeusten euscaldum gustiai $(1731,1)$ ofrecietandeusten gustiai $(1758,1)$, Cavalleroari $(1731,1)$ / Caballeroari $(1758,1)$, poderoSSoagan $(13)$ / poderoSoagan (17), poderoSsoagan (14) / ponderoSoagan (sic 19), ConfeSsetea (19) / ConfeSetea (24), ConfeSsinocoen (43) /Confesinocoen (50), sepulta tua (14)/sepultadua (18), ilen arterean (14) /illen artetic (18), gacherean (16) / gachetatic (21), Igoeban (14) / Igoeben (18), jaSSarriric (14) / jaSarriric (18), Leleengoa (14) /Lelengoa (19, 24, 26 ; 22. or. : Leleengo), guizonazan (15) /guizonadan (19), Juyzioco (16) /Juycioco (20), gueStoai (16 /gaiStoai (20), penea (16)/pena (20), vorondatea (16) /borondatea (20, baina 55. or. vorondate), vorondateagaz (25) /borondateagaz (30), salbacinoa (46) /salvacinoa (53), errecividu (53) /errecibidu (60), celan (16) /nolan (20), icena (16) /izena (20), iguçu (16) /iguzu (20), dogula (17) /degula (22), ezer (18) /ecer (23), Oneec $(18,43,46,48) /$ Onec $(23,49,53,55$, baina 54 . or. Oneec), Curuce (20) /Guruce (25), beardau (20)/beardu (25), Zeñatutea (20) /Ceñatutea (25), Curuze (20) /Curuce (25), curuzez (21) /curucez (25), Curuzeoc (21) /Curuceoc (25), Curuzean (47) /Curucean (54), echizerietan (36) /echicerietan (42), zaitudaz (23) / zaytudaz (28), errazoien $(24,43)$ /errazoyen $(29,49)$, ja io (29) / ja yo (34), jaiaqueran (29) /ja yaqueran (34), gueiago (31,45, baina 48. or. gueyago) /gueyago $(36,52)$, ba ia (45) / baya (52), Jaungoicoa (25, 45, baina 48. or. Jaungoycoa) / Jaungoycoa (29, 52), gazteago (26) / ga Steago (30), guztiac (39) / gustiac (45), ezerbere ezereanic (27) /ecerbere gañic (32), peccatuac (27) / pecatuac (32), emaiten (27 /emayten (32), Biortuten (30)/Biurtuten (36), gorpuceraco (34) /gorpuzceraco (39), gorpuzeco (51) / gorpuceco (58), arimaraco (34) / Arimaco (39), gorpuzetacoetaric (35) gorpucetacoetaric (41), verbeagaz, obreagaz, da deseoagaz (37) /berbeagaz, da deseogaz (43), haziendea (38) / haciendea (45), Pazcho (39) / Pazco (46), ErreSurrecinocoetan (39) /ErreSurreciocoetan (46), Oguetabat (40) /Ogueitabat (46), Bauptismoa (41) /Bautismoa (47), alcarregaz (43) /elcarregaz (49), joangoda (43) / juangoda (49), Ceimbat (44,45) / Ceinbat (51), ezarrileiaSaco (45) ezarrileyaco (52), pelliburo (46) / pelliburu (52), ilen (48) /illen (55), ardauric (50) /arduaric (58), Biac bardin (51) /Ez; biac bardin (58). Bestalde, Larramendik 1731 ko edizioan diren hutsak zuzentzen ditu Corografiako "De los dialectos del vascuence..." atalean. Dotrinako 20, 21 eta 22. orrietan diren zatiak hartzen ditu : "Corregiré las erratas que tiene la impresión, que es de Vitoria" : orcoroagaz (Arz.) : arcoroagaz; diriala : direala ; ce : cer ; Leleengoa : Lenengoa; sur: sudur; Santeen : Santearen; puntaric: puntatic (-ric guztiak: -tic; ganeric: ganetic; alderic : aldetic etab.) ; Jaungoycoa : Ja ungoicoa; azagaz:atzagaz; zeñatu-: ceñatu-; azac: atzac: curuce, curuze : curutze (beste guztietan ere $t z$ idatzi du Larramendik). 
Beste testuinguruetan $<\mathrm{z}>$ darabil :

Dezala $(1,3,6 \ldots)$, errezacea $(1)$, ezauera $(1,2,3,6)$, ezadazu $(1)$, ezaungarri $(3,6)$, gauza $(1,2,3,5 \ldots)$, gozoa (3), luzaro $(1,2,3,6)$, nazala (1), traza $(2,7,8)$, uga zaba $(1,2)$, zagozaten $(3,4)$, za la $(1,2,3 \ldots)$, zoragarria $(2)$, zoraqueria (1) etab.

Hauetako zenbait hitz beste era honetara ere idatzita ageri dira : baisic, esadazu, ugasaba, bi hotsen arteko nahasketa agerian utzirik. Ondoko hitzetan egin diren aldaketak ere horren lekuko dira : a sicea : azicea, Aurchoac naiquerien artean, eta erregaluen artean a sicea / azicea (2); Emastea : Emaztea (1); esconceco : ezconceco (1) ; espata : ezpata $(1,6 \text { or. })^{14}$; gusti : guzti (1) ; gustia : guztia (1. Hurrengo lerroan ez da zuzentzen) ; gustitic : guztitic (2) irabasten : irabazten (1). Halaber, ezan : esan (1) ; ezadazu : esadazu (1) ; iguez : igues (1) ; zaldu : saldu (2) ; zartuceco : sartuceco (2). ${ }^{15}$ Ondoko hauek, berriz, ez dira aldatzen : baisic $(1)$, eznatu $(2,6)$, eznaturic (3), gausa (1), nahazturicg (2), pisuscoa (2), siniztuco (1), ugasaba (1) ; baina honela ere ageri dira : baizic $(1,2,3 \ldots)$, esnaturic $(3)$, gauza $(1,2,3 \ldots)$, nahasturic (6), pisuzcoa $(2,6)$, sinistu $(1,2)$, sinisquera (1), ugazabai $(2)$. Hala ere, corpus osoan gauza hitzak, esaterako, 93 agerraldi ditu eta ga usak bakarra ; baizic ere 24 aldiz ageri da eta baisic behin bakarrik.

$<\mathrm{z}>$ eta $<\mathrm{s}>$ ren arteko zalantza hauez gain, nahiz eta ia guztiak zuzentzen dituen, lehen eskuizkibu hauetan frikariak eta afrikatuak ez dira idazkeran bereizten, $e$ eta $i$ bokalen aurrean $<\mathrm{c}>$ nagusi izanik ere eta besteetan $<\mathrm{z}>.{ }^{16}$ Hala ere, $/ \mathrm{s} /$ hotsaren idazkeran $e$ eta $i$ bokalen aurrean $\langle\mathrm{c}\rangle$ eta $\langle\mathrm{z}\rangle$ txandakatzen ditu hitz berean, baina ondotik egin zituen aldaketek $<\mathrm{z}>$ ren aldeko jarrera erakusten dute. B-k, aldiz, hots hau irudikatzeko $\langle\mathrm{c}>$ darabil $e$ eta $i$ aurrean : bicimodua, zucenbidea etab. eta beste testuinguruetan $<\mathrm{z}>$ : eguizu, zoco etab.

- TS. $<\mathrm{s} / \mathrm{c}>\lim <\mathrm{ts}>$

losagabe : lotsagabe (1). Lehen agerraldia soilik zuzendu du, tartean losagabeac, losa ga betasun eta losa garrria bai baitira. Sermoiaren amaieran, berriz, lotsa ga beric, lo tsa ga bezcoric eta lotsa garriori darabil. Zehazki hitz hau ondoko eskuizkibuetan beti $<$ ts $>\mathrm{z}$ idatzita ageri da.

Ecai A : etsai B (1). ${ }^{17}$ Birritan zuzendua, baina bigarrenean esari idatzi zuen A-k : Berala alde eguin zuen Esari / etsai gaiztoac. Bigarren sermoian ere esa ri ageri da zuzenketarik gabe : O, Jesuchristoren Esa ri guzziz gogorrac!

Zuzenketa hauetatik kanpo $<\mathrm{s}>$ da nagusi :

a seguin $(3,6)$, a seguinic (4), isa sotic, isa soac (3), isusi $(2,3)$, isusitasun (3), ${ }^{18}$ useguin $(1,3,6)$, useguiten $(1)^{19}$ etab.

Hots hau $<\mathrm{z}>\mathrm{z}$ irudikatua ere aurkitu dugu txistukariak bereizten ez dituelako, baina guztiak aldatu ditu honela :

14 - Lerro batzuk beherago espata ez dago zuzendua. Lehenengo orrian, berriz, ezpata irakurtzen dugu. 15 - Jarraian, halaber, sartucen dio, eta ez sarcen.

16 - Azken eskuizkribuetan bada jarrera aldaketa bat, nahiz eta oraindik grafia horiek ere ageri diren. Cf. 4. 17 - eca i [Gainetik zuzendua dago eta azpikoa ez da garbi irakurtzen :] ecai, ecari (?) [Aldaketa argiago gera zedin edo, orriaren ertzean ere etsa $i$ idatzi zuen zuzentzaileak].

18 - lotsa ga rrita sun-en alboan, lerro berean.

19 - 7., 8. eta 9. eskuizkribuetan, berriz, < ts> ageri da ondoko hitzetan : atseguin, atseguiñac, atseguiñetara $(7,8,9)$; otso (9), otsac (9), utsac (9), utsean (9). 9.ean zuzenketa pare bat egiten du : atzeguin atseguin, otzeguiten otseguiten. Badira, ordea, isusi eta isa soac modukoak ere. (7. testua 1742an ekoitzitako paperean idatzia da. Cf. 2). 
uzic: usic, a macean uzic / usic batere eguin gabe (2).

izuziac : isusiac (2). Aldaketa bakarra, beste guztietan < s> ageri baita (isusi, isusiac, isusita sun, isusita suna).

pisuzuac : pisusuac (1. Lau lerro beherago pisusua ageri da)

Honetan ere, salbuespenen bat gorabehera, ez dira idazkeran $\mathbf{t} \mathbf{s} /$ eta $\mathbf{S} /$ hotsak bereizten baina irakurketa ezberdin hauek, jakina, ez dira testuan bertan aurkitzen. B-ren idazkera, haatik, bestelako da < ts> baitarabil zuzenketa hauetan ez ezik morfologia mailan egin dituenetan ere : etsi etsian.

Ezaguna da $<$ ts $>$ lehenengoz Leizarragak erabili zuela, Etxeparek $\langle\mathrm{x}\rangle$ zerabilen bitartean. Larramendik orokortu zuen <ts $>$ : "Aprendan los nuevos traductores a escibir esta pronunciación miretsi como la trae Axular, desterrando de ella la $x$ que importunamente añaden, etsi, etsia n, ardietsi, onetsi, ga itzetsi y otros" [Corografía 298]

Laburbildurik, testuen egilea ezagutzeko garrantzi gehiago duten < tz> eta $<$ ts $>$ ren erabilerak kontuan hartuz ondoko jarrerak ditugu :

\begin{tabular}{|c|c|c|}
\hline & A & B \\
\hline$T Z$ & $\left\langle\mathrm{c}^{\mathrm{e}}, \mathrm{i}\right\rangle$ eta $\left.<\mathrm{z}\right\rangle$ & $<\mathrm{tz}\rangle$ \\
\hline$T S$ & $<\mathrm{s}\rangle$ & $<\mathrm{ts}\rangle$ \\
\hline
\end{tabular}

Begi-bistan dago A-rena ez doala Larramendik aholkatzen eta zabaltzen duen bidetik: "Finalmente dos pronunciaciones se harán dificiles à algunos, y son las que traen $t z$, ts, y sin embargo son muy suaves, y dulces, v.g. otzá frio, gatzá sal, hitzá palabra : y otsá ruido, lo tsá verguenza, (...)". [El imposible vencido 339]. ${ }^{20}$

Besterik da B-ren joera, Larramendirenaren parean baitoa. Nolanahi ere, badukegu oraindik susmo hau indartzeko arrazoirik.

Larramendiren Azkoitiko sermoian $(1737)^{21}$ hitz hauek aurkitu ditugu $<\mathrm{tz}>,<\mathrm{ts}>$ :

vicitza, bacoitzac, biotza, biotzic, deritzan, etzigola, etziranac, garratza, gurutzearen, jaiotza, ja sotzeco, ondatzen, oñazpicotzat, cecartzien, atseguinez, a utsi, etsaien, itsusi, liquitsaquin, lotsea, otsa, uts, utseguitea ;

$<\mathrm{n}>$ ren ondoren badira honelakoak : anza, aranzetan, enzun, eranzuera, eranzungo, eranzuten, janci, baina testuinguru horretan ere nagusi dira : a rintzen, itantzen, la guntzen, la guntzeco, cerentzat, cintzoac, etab.

Kardaberazek ere gomendatu hala egiten du Eusqueraren berri onac eta ondo escribitceco, ondo iracurtceco, ta ondo itzeguiteco Erreglac (1761) liburuxkan, baina izenburuan bertan erakusten digu erabileran dituen zalantzak (cf. Altzibar 1991 : 265). Christa va ren bicitzan 1744 ? eta 1760 ko edizioetan ere $e$ eta $i$ bokalen aurrean $<\mathrm{tç}>$ da nagusi lehenean eta 1760koan < tc $>$ :

costatçen (142), iga rotçen (142), a ditçeac (87), cinatçera (169), salva tçeco (183), contatçen (71), batutzeco (153), iragotzen (107), gogoratzen (135) etab.

(1760 :) tratatcean (124), bolatzea (138), erregutcen (4), jasotcen (130), utci (181), etciran (93). 1762edo inguruko dotrinan ere $<\mathrm{tc}>$ darabil : curutce (4), curutceac (17), goputceco (34) quentceco (51) etab.

20 - 1729ko edizioa erabili dugu.

21 - Aita Beraza eta Aita Agirretxe frantziskotarren eskutik Zarauzko Frantziskotarren komentuko artxiboan den jatorrizko eskuizkribua eta J. Lakarrak argitaratua (1985) erabili dutugu. 
Mendiburuk eta Larizek (ezagutzen dugun 1773ko edizioan), berriz, maisuari jarraitzen diote. Besterik da, Otxoa Arinen, Arzadun (1731-1758) durangarraren eta Irazuztaren joera. Otxoa Arinek < ts $>$ badarabil (pentsamentuaz 172, iracatsi 56, etsa y 39, etsa ya 73) baina $<\mathrm{tz}>$, $<\mathrm{tc}>$ zein $<\mathrm{tç}>$ (ik. goian $<\mathrm{zc}>$ ere) eta $<\mathrm{z}>$, $<\mathrm{c}>$ nahiz $<$ ç> erabiltzen ditu :

$<$ tz> : ateratzearren (168), corputza (27), deritza (37), deritzo (143), dirautza (66), erantzutea (26), ga itz (167), ga itza tzu (1), ga itza requin (157), itz (60), vicitzara (66), ventzutu (54) etab.

$<$ tc $>e$ eta $i$ bokalen aurrean soilik darabil : a matceco (17), biurtcen (66), concientcia $(154,163)$, egotci (157), eutci (80), ezagutceco (17), itceguin (156), gozatcen (37), libratceco (40), mantenitcen (24), sortutceco (24), zatitcen (4) etab.

< tç> : Amarrenarentçat (154), citçaten (164) corputçaz (79), dirautça (71), ditçaque (23), gorputçaz (161), itçari (161), itçaz (69), etab.

$<\mathrm{r}>$ ondoren $<\mathrm{tc}>$ idazten $\mathrm{du}$ :

artcea (168), biurtcen (66), zortci $(102,154)$, zortcigarren (167), etab.

<z> \$s/: dituzu (19), eleizeac (154), ezagutuco (69), gauza (27), gauzea (68), guizona (11), izan (68), izango (61), izateco (61), izen (10), zayo (129), zorrac (1) etab.

< ç> : diçut (70), eleiçaz (41), eleiçan (41), ga uça $(71,169)$, guiçon $(25,26)$, içan (27), içanaz (70), izanduçan (27), çayon (164) etab.

$<\mathrm{c}>$ beti $e$ eta $i$ bokalen aurrean erabiltzen $\mathrm{du}$ :

baicican $(1,20,21,30)$ becela (62), ceña (27), cerren (143), ceruetara (3), ciraucun (63), ecin (78), guciac (31), gucia u (27), mereci (60), noticia (62), obedecitua (143), suceditu (7) etab.

Larramendik <ç> dela eta, honela diosku : "también debe desterrarse la cedilla o la ç, que en España ha estado también en uso, y hacen su oficio la $c$ y $z$ con las vocales correspondientes" [Corografía 298]. Esan daiteke <ç> honekin batera $<$ tce $><$ tci $>$ eta $<$ tçe $><$ tçi $>$ Larramendik baztertu zituela, testuinguru guztietan $<\mathrm{tz}>$ sartuaz, goiko adibideetan ere (AS) ${ }^{22}$ ikusi dugun gisan.

Arzadunek, berriz, ez ditu frikariak eta afrikatuak bereizten. Hala ere, 1731 eta 1758 edizioen artean bada batzuetan aldaketa bat honetan, $e$ eta $i$ bokalen aurrean gehienbat $<\mathrm{z}>$ ageri baita 1731 ko edizioan eta $<\mathrm{c}>1758$ koan :

Curuze (20)/Curuce (25), curuzez (21)/curucez (25), Curuzeoc (21)/Curuceoc (25), Curuzean (47) /Curucean (54), echizerietan (36) /echicerietan (42), ezer (18) / ecer (23), gorpuzeco (51) / gorpuceco (58), gorpuzetacoetaric (35) / gorpucetacoetaric (41), haziendea (38) / haciendea (45) etab. baina : icena (16, 1731) /izena $(20,1758)$.

$<\mathrm{z}>$ nahiz $<\mathrm{c}>$ bi edizioetan :

bederazigarrena $(18,1731$ - 23, 1758), baliz (48-56), janciric $(46,52-53,59)$, vioceco (44-50). 
$<\mathrm{z}>$ darabil bi edizioetan $a$, $o$ eta $u$ bokalen aurrean :

bazuc $(46,52-53,59)$, gorpuza (30-35), onzat (53-61), azac (21-25), izanic (52-59), meza (19-24), zareanea (52-59), zorrac (16-21), viciza (39-45), voza (52-60), eriozaco (39-45) etab.

< s> bietan : lossaric (47) / losaric (54), deusut (46, 48-53, 55), falsoetan (36-42), pensamentuetan (37-43).

Irazuztak < ts> erabiltzen du (arratsean 4, etsayaren 2, jetsi 8, etsairic 43, itsusi 62 , lotsaz 62 etab.), baina $<$ tz> $a, o$, eta $u$ bokalen aurrean soilik darabil :

bacoitzac (27), beatz (11), corputza $(39,53)$, eriotza (8), Esperantza (35), gaitzatzu (24), itzac (49), itza tzu (31,33), litza teque (37), vicitza (39) etab.

$<$ tc $>e$ eta $i$ aurrean :

aditcen (30), a guintcen (30,32), ga itcic (30), gurutcea (2), itcez (48), ja sotcea (7), libratceagatic (3), sartcea (2), utcitcen $(34,47)$ etab.

< z> \$s/: eliza (13), ezazu (11), gauza (37, 38), guizona (19), iza tea (19), izandu (19), zaite (3), zuala (68), etab.

$<\mathrm{c}>e$ eta $i$ aurrean idazten du :

baicican (18), barcacioa (2), cenduan (12), cergatic (33), becela (36), gaitecela (30), obligacio (69), ofrecituco (49), recibitu (13), viciric (56), vicitza (39) etab.

Zegamako dotrinan ere usadio bera dugu : eutci (28at.), corputcean (31), corputcetic (31), baina : bazuec (27at.), batzuec (44), bacoiza (35), viotza (42), enzuten (46) etab. ${ }^{23}$

Hona hemen laburbildurik, salbuespenak albo batera utzita, Larramendiren aurrekoen jarrera eta eskuizkribu hauetan (lehenengoetan) ageri dena parez pare :

\begin{tabular}{|c|c|c|c|}
\hline & $\mathrm{TZ}$ & $Z$ & TS \\
\hline Otxoa A.(1713) & $<\mathrm{tc}>/<\mathrm{tç}>/<\mathrm{tz}>$ & $<\mathrm{c}>/<c ̧>/<\mathrm{z}>$ & $<\mathrm{ts}>$ \\
\hline Arzadun (1731 & $<\mathrm{c}>/<\mathrm{z}>$ & $<\mathrm{c}>/<\mathrm{z}>$ & $<s>$ \\
\hline Irazuzta (1739) & $<\mathrm{tc}>/<\mathrm{tz}>$ & $<\mathrm{c}\rangle /<\mathrm{z}\rangle$ & $<\mathrm{ts}>$ \\
\hline Eskuizk. A & $\langle\mathrm{c}\rangle /<\mathrm{z}\rangle$ & $<\mathrm{c}\rangle /<\mathrm{z}\rangle$ & $<\mathrm{s}>$ \\
\hline Eskuizk. B & $<\mathrm{tz}>$ & $\langle\mathrm{c}\rangle /<\mathrm{z}>$ & $<\mathrm{ts}>$ \\
\hline
\end{tabular}

\subsection{2. $\mathrm{H}-\varnothing \mathrm{h}$}

iz A : hitz B (1).

Arlo honetan ere aurkitu dugun zuzenketa bakarra esanguratsua bezain adierazgarria da, honen egilea B delako. A-k beti $<\mathrm{h}>$ rik gabe idazten ditu hitzen eratorriak eta erakusleak :

iz, iza, izac, izqueta, izquetan, etab. ; au, ori, ura.

Erdal jatorrizko hitzetatik at (deshonesto, deshonrra, deshonrrazat, habituala, herederu, herencia, honestoa ren, honrra, humilde, humillacen, etab.) hurrengoetan ezartzen du (corpus osoan) :

23 - Ik. zehaztasun gehiago F. Ondarrak argitaratu zuen "Zegamako Doctrina Christia na (1741)" lanean. 
hume $(1,8,9)$, humeac (1), hi (2: hi izan adila), ohosturic (9), a haztu $(1,8,9)$, a ho (1, birritan), a hoetan (1), ${ }^{24}$ a hoac (2), a ha sabac (9), a teach (2), a theetan $(6,9)$, ehocen (8); ithoce $(1,8)$, loho $(8,9)$, lohotan $(8,9)$, na hasturic $(6)$, na hazturicg $(2$, birritan), ega ha, egahaca (1), esnahatu (9), eznahatu (8). [cf. Mitxelena 1979: 213-220].

Baina : ume, umeac, umechoa, umeenzat (2), ostucen (6), a oetatican (1), a oan (2), ateetan (8), a teetatican $(2)$, itoric $(3,8)$, itoceco $(2,3)$, itocen $(3,9)$, na asturicg $(2)$, ega (1), eznatu $(2,6)$, esnacen $(8,9)$.

Larramendik, alde batetik, hitz hoskide batzuk bereizteko proposatzen du eta, bestetik, errespetatu egiten du ahoskeran oinarritutako iparraldekoen usadioa :

La hache, ò aspiracion està muy en uso en Labort, Baxa Navarra, y Zuberoa, assi en lo hablado, como en lo escrito, pero no en los dialectos de España, como ya lo tengo dicho : y aunque no se aspirasse la hache me inclinaria à que se escribiessen con ella muchas voces como en Francia, para distincion del significado. Pongo exemplo : ori ori ori, parece una voz y son tres distintas, que significa to ma esso a ma rillo, y se debieran distinguir assi : óri orí hori;

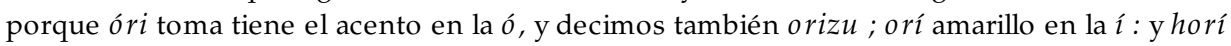
esso tambien en la $i$ pero tuviera distincion en la $h$ con que se escriben y pronuncian essa voz en Labort, aunque nunca es gutural esta aspiracion como lo es en Andalucia. Lo mismo digo de hurá aquèl, urá agua, haria carnero, aria hilo, haur este, que nosotros decimos a u, y aur, a urra niño ; y assi de otras muchas voces. Pero en esto tampoco me desagrada la indiferencia, y assi, escribiré unas voces de un modo, y otras de otro [HH xxxviij-xxxjx or.] $]^{25}$

Las voces aspiradas apenas tienen lugar en los Bascongados de España, aun las que en lo escito llevan la $h$, ò la aspiracion : pero tienenle en los de Francia, donde es muy frequente. En esto cada Provincia guarde su estilo, como en el tonillo particular de la voz. [El imposible vencido 337-338. or.]

Azkoitiko sermoian hitz hauetan darabil : hipuynac, hume, humeac, humeric, hura, hitzeguin, hori, hitz, hitzic, hizcunde, hizcunderen, hizcho, hizqueta. Maileguetan $<\mathrm{n}>$ ren ondoren < r $>$ bakuna idazten du (honragarria, honretan, deshonragarri) A-k ez bezala : honrra, deshonrra, deshonrrazat.

Kardaberazek, haatik, Larramendiren ikuspegi horretatik aldenduz hasperenketaren aurkako jarrera adierazten du :

Achea letra dan, edo ez, Autoreen artean eztabaida andiac dira. Naiz letra, naiz aspiracioa dala, edo beemenciaz soñu gogorra ematen duena, emen gure Eusqueran, ta Bizcaian, Ache ori alferricaco, edo servitcen ezduen gauza da. H ori izquetan batzuec Ge, besteac Jota eguitendute. Guc orrelaco aspiracio begemente edo behementeric usatcen ezdegu. Abrahan esateco, Abrajan diote. Quen ortic : gure Eusquera suave eztizcoarenzat soñu ori ezta [Eusquera ren berri onac 23. or.].

Gure helburua eskuizkribu hauek ez zituela Larramendik idatzi erakustea izaki, $<\mathrm{h}>$ aren erabilerak ere, goian ikusi ditugun puntuetan bezala, ez du bere egiletasunaren alde hitz egiten.

\subsubsection{Bustidurak}

2.1.3.1. Albokarietan zuzenketa bakarra aurkitu dugu :

nadila A: nadilla B (1), emen illic guelditu nadila / bertan il nadilla.

A-k nadila ez ezik, ondoko aditz forma hauek ere < il> idazten ditu :

24 - aoetan [-h-ondotik erantsia :] ahoetan [Aurreko lerroan aoetatican irakurtzen dugu. Hitz hau Arzadunen dotrinan (1731-1758) ere $<\mathrm{h}>\mathrm{z}$ idatzita ageri da : ahoen (21-26), a hoco (44-50)]

25 - 1745eko edizioa erabili dugu, paperaren ur markak ere ikus daitezkeelarik. 
adila (2), dedila $(1,3,8,9)$, cedila (3; 6. eta 7. idatzietan, berriz, zedila), dabil, dabilela $(3,8)$, badabil (9), bazebilen (8).

Bestenaz, < illV> da nagusi :

illic $(1,3)$, ibilli $(1,3)$, illun (4), biraoguille (1), milla $(1,4)$, juramentuguille, juramentuguillenzat $(1,4)$, zillarrezco, zillar $(1,3)$, billacen, billaceco $(2,3)$, doillorrari (1), ucabillada (2), mutilla ri (2), illova (2), ma quillac (2) ${ }^{26}$ etab.

Doillorrari-k agerraldi bakarra du, baina ondokoetan $<$ ll $>$ idazten du : dollor, dollorragatica $n$, dollorragoa $(1,2$. eta 7 . idatzietan). Halaber, $<-$ zalle $\rangle$ : gordezalle $(-a, a c, 2)$, pagazalle (1) eta servizalle (-tican, 1$)$.

Testuinguru honetan Larramendik ere usuenik < ill> darabil (AS) : iraillean, pilla, illarguiaz, billatzeco, illic, onguille, gaitzguillea, isillic, milla, ibillico, bacebillen, dabillenic, dedilla, cebillen. Azken lau forma hauek A-k < il $>\mathrm{z}$ idazten dituela ikusi dugu goiko zerrendan. Arzadunek 1731ko edizioan $<\mathrm{l}>$ darabil eta 1758koan, berriz, < ll> : ilen $(14,48)$ /illen $(18,55)$, baina ez beti : ilac $(31-36)$.

Badira A-ren idatzietan, hala ere, $<$ ilV $>$ : ibili $(1,2)$, erabili $(1,2)$, ilabete (2), ilunaz, ilun (2), iluntasuna (3), ilecho, ilean (2), ibiltera (3).

Hitz bukaeran nahiz kontsonante baten ondoan zalantzak ageri dira :

ill $(3,4)$ /il (1,2), illtera (3), illten (4) /ilten (2), illteraco (6) /ilteco (2), ilgo (-co, $2,4)$, ibiltea, ibilteac $(2,3) .^{27}$

Larramendik hitz amaieran bezala, ez dirudi -llK beharrezkotzat jotzen duenik Azkoitiko Sermoian ondoko hauek baitira : iltzen, iltze, isilta sunic, ibiltea; il, isil. B$\mathrm{k}$ egin duen zuzenketan ere hitz amaieran <l> darabil : il (ik. aurrean testuingurua).

2.1.3.2. Sudurkariari dagokionez, ondoko zuzenketa ageri da :

zeinzuequin A : ceñaquin B (1. Azken aldaketa hau ez da zehazki grafiari begira egina, jakina).

Testuinguru honetan, hala ere, A-k gehienbat $<$ (i) $\tilde{n}>$ idazten $d u$ :

azquenerañoco (3), desengaña (3), Erreñuraco (3) / Erreiñu (1), españac (3), Gañetic (3), la iñoari (1), ceñaren (3), zeinac (3) /zeiñac (2), baina : beinere $(1,2,4)$.

Diptongo $-i$ batez ere- ondoren kontsonantea dagoenean, berriz, $<\mathrm{n}>$ da nagusi :

beingo $(1,3,6)$, beingoan $(1,2,3)$, beinzat $(1)$, zeinbat $(1,2)$, zeinda $(1,2,3)$, zeinzuec $(1,2)$, baina : biguñcen $(3)$.

Hitz amaieran diptongo ondoren ere $<\mathrm{n}>$ aurkitzen dugu :

a pain (2), bein $(1,2,3 \ldots)$, duin $(2,3)$, edocein $(1,2,3)$, mandazain $(1)$, oin $(1,2)$, orain $(2,3,4 \ldots)$, zein $(1,2,3)$.

$<\tilde{\mathrm{N}}>$ aurreko $i$ dela eta, Larramendik Kardaberazi ondoko aholku hau ematen dio :

$26-6 ., 7 ., 8$. eta 9. idatzietan ere gehienetan < ll> idazten du : billa $(8)$, billacen $(6,9)$, ibilli $(7)$, illa, illac $(8,9)$, illa betean $(7)$, illic $(6,8,9)$, illumpe $(8)$, illuntasun $(6)$, ispillua $(6,9)$, mesedeguille $(6)$ etab. 27 - 8. eta 9. eskuizkribuetan ere badira honelakoak: ilten, iltea, ibiltea . 
"Escríbase aiñ, ceiñ y no a ñ, ceñ". ${ }^{28}$ Izan ere, Kardaberazek testuinguru honetan gehienbat $<\tilde{n}>$ darabil bere idatzi gehienetan. Larramendik, berriz, hitz bukaeran $i$ idazten du baina zalantzak ageri dira $<\mathrm{n}>/<\tilde{\mathrm{n}}>$ artean (ain / a iñ , edocein / edoceiñ, orain /oraiñ, cein /ceiñ).

Badira $<$ iñ $\mathrm{V}>$ eta $<$ in $\mathrm{V}>$ ere baina zalantza batzuk gorabehera $<$ iñ $\mathrm{V}>$ da nagusi :

a seguiñeraco (6), bea rguiñen (1), diñoan $(1,3,5,6)$, eziñic (1) /baina ezinic $(1,3)$, iñoiz (2), iñolaco (1), iñori (1), la guiña (1,2), miña (1), onguiña (6), ora inguiño (1), pemiña $(4,6), \operatorname{siñu}(2)$, siñucen (2), siñuqueriaren (2), useguiñen (3) etab.

$<$ in $\mathrm{V}>$ :

anzinatic $(1,3)$, arina $(1,6)$, burdinara $(3)$, efini $(1,2,3)$, efinico $(3,4)$, eguinen (1), ezina (4), imagina $(3,6)$, Inude (1), sinistu $(1,2)$, Virgina $(1 . .$, beti $<\mathrm{n}>\mathrm{z}$ idatzita ageri da).

Aipagarria da A-k lehen eskuizkribuan bustidura grafian esanahia bereizteko egiten duen zuzenketa : miñac (mihia) : miac; minetatican : mietatican; min : mi.

Larramendiren lanetan ere $\langle\mathrm{iñ} \mathrm{V}\rangle$ da ugariena. Kardaberazek ere teorian $<\tilde{\text { n }}>$ dunak hobesten ditu (Eusqueraren berri onac 25. or.) baina idatzietan (Egerc. II, III) zalantza batzuk ageri dira.

Hitz bukaeran < in > da nagusi :

-(ar)equin (soziat. salbuespenik gabe), a leguin $(1,2,3,4 \ldots)$, a rin (1), a seguin (3), bardin / berdin (1), dedin $(1,3)$, eguin $(1,2,3,4 \ldots)$, min $(1,2)$, ezin (1), ziquin (2), baina : miñ (1), gazmiñ (6), useguiñ (6).

Larramendik testuinguru honetan ere gehienbat $<$ in $>$ darabil :

baldin, eguin, ecin, jaquin, -(ar)equin, guciaquin, utseguin, a tseguin etab. Baina: miñ, fiñ. (AS).

\subsection{4. $\langle$ ss $>,\langle x\rangle,\langle\mathrm{j}\rangle,\langle\mathrm{g}\rangle$}

Hauetan ez da inolako aldaketarik egin baina hitz pare bat esan nahiko genituzke egilea ezagutzen lagunduko digutelakoan.

<ss> digrafoa ere ageri da, batez ere 8. eta 9. eskuizkribuetan, baina hori latinaren ortografia errespetatu nahiari zor zaio :

passijo (5), passijoa (5), confessio $(3,8,9),{ }^{29}$ confessioa $(-z, 8,9)$, confessioraco $(9)$, confessioric (9), aprenssio (6), aprenssioan (6), essencial $(5,8)$, excesso (8).

Alabaina, essencial eta passijo hitzak izan ezik, beste guztiak < s> bakunaz ere idazten ditu :

28 - Honela erantzuten dio Kardaberazek : (...) en el impreso de las reglas del bascuence, puse que era mejor omitir la $i$, que no se dice ni suena, y lo tengo por más acertado, y porque me parece perfección en su modo el usar de menos letras cuando no sirven sino de embarazo. V. Rev. me enseña esto, pues pone en el Diccionario dañua, maña. Son estas y otras muchas voces bascongadas y omite V. Rev. la $i$, y a sí sucede en las castellanas, igualmente bascongadas: Aña, Año, baño beña (...). Me parece justo se me haga equidad y guarde yo consequencia, siguiengo a V.Rev. por maestro y no a los franceses que van por otro camino : En la ortografía a V. Rev. quiero por maestro y no a ellos. [Cf. Tellechea, 1968, 1990:313]

29 - Confessio hitza, adibidez, < ss> z idatzita azken eskuizkribuetan dituen agerraldi horietatik kanpo 3.ean soilik aurkitzen dugu, bertan eta lehen nahiz bigarren eskuizkribuetan $<\mathrm{s}>$ bakunak nagusi direlarik. 
aprensio (6), confesio $(1,3,8)$, confesioa (3), confesioac $(1,2)$, confesatu $(1,2,3$, $6,8,9)$ etab., excesoari (1).

Larramendik eta Kardaberazek ere <ss> erabiltzen dute horietako zenbait mailegutan : passio, passioco (AS) ; confessio, confessore, confessatu, confessioan etab. (Egerc. I, Christavaren bicitza). Larramendiren hiztegian etimoetan (assalda), etimologiaz bermatutako maileguetan (assomatu) eta euskal hitzetan ere agertzen da (asserraldi, nahassi).

$<\mathrm{x}>$ grafema darabil $\breve{s} /$ hotsa irudikatzeko :

a uxen (3), orixen (9), uraxen, a laxe, onelaxe, ga ixo (3), gaixoa, ga ixoac, ga ixoai, gaixoaren, gaixoarequin, gaixoari, gaixoric, ${ }^{30}$ ixuri (5), moxal (2), moxalac (2), a rex (bat. 2), lexar (2), Anaxe baina bada Anage ere.

Anaxe / Anage : agerraldi guztiak 2. eta 9. eskuizkribuetan kokatzen dira eta bietan $<\mathrm{g}>\mathrm{z}$ nahiz $<\mathrm{x}>\mathrm{z}$ idazten du: Anagechoac Anagechoequin (2), eta a raco Anaxe, edo Tutore, Gurasoac bezela, (2), Nerezat Adisquide ta Anage (9), il zaizun Anaxe asco (9) etab. ${ }^{31}$

Larramendiren Artean (298. or.) ere "igiltze onarí, déritza Sancho, al buen callar llaman Sancho" irakurtzen dugu ; halaber, HH-n : igild u, igila ra ci, igilera zo 'acallar', igildua 'callado', igildo 'mudamente', igilic 'cepos quedos'. Gogora dezagun etorkiz $\langle\mathrm{x}\rangle \mathrm{k}$ sabaiaurreko frikari ahoskabea $\breve{s} /$ ordezkatzen zuela gaztelaniaz eta $<\mathrm{j}\rangle \mathrm{k}$ $(<\mathrm{g}>e$ eta $i$ aurrean) kide ahostuna $\breve{\mathbf{z}} /$, gero XVII. mendearen lehen herenerako biak ahoskabetu eta $/ x /$ bilakatu ziren arte. Hots berriak, ordea, lehengoen grafiak $(<\mathrm{x}>$ eta $<\mathrm{j}, \mathrm{g}>)$ luzaro mantendu zituen, XIX. mendera arte ez baitzen arautu $<\mathrm{x}\rangle$ ks/adierazteko bakarrik erabiltzea. ${ }^{32}$ Eskuizkribu hauetan $\langle\mathrm{x}\rangle$ grafema ageri da hainbat mailegutan :

consexu $(3,6,8)$, crucifixo (4), exemplocho (3), exemplo $(1,2,3,8)$, exemplar (7), exercitu (8), exercicio (2), embaxadoreetatic (9), monxa (2), personaxeric (7), luxuriosa (2), proximoaren $(1,3,6)$, a ntoxu (2. Ikus lexikoan B-k hitz hau gurariaz ordezkatzen duela); halaber, examinatu $(1)$, experiencia $(8,9)$.

Arzadunek ere proximoen (18), expliquetan (20), explicacinoa (24), examina (44) idazten du. Otxoa Arinek : poximoaren $(4,169)$, luxuriaco $(4)$, explicatuco $(26,70)$, pretexto (161). Irazuztak, berriz, esplicacioa (56), progimoac (36), esaminatceco (49) baina : proximoaren $(6,7,31)$, luxuria $(31,40)$, luxuriaco $(30)$, excelenteagoa (15), examina (60).

Hots hauek idatzizko nahasbideetatik atera nahiak makina bat buruhauste eragin zien Hegoaldeko euskal idazleei (cf. Mitxelena 1978 : 393, 1979 : 224-225). Honela adierazten du Larramendik :

Algunas palabras se escriven con $x$, pronunciada no guturalmente, sino à la Latina ò estrangera, v.g. ori orixe, a laxe \&c. Que se inclina à la pronunciacion de oisie, alasie. [El imposible vencido, 338. or.]

Tres o quatro pronunciaciones se hacen difíciles a los que no saben el Bascuence y le quieren aprender, y hablo de los Españoles, porque para otras Naciones no lo son, como 30 - Baina badira $<\mathrm{z}>$ eta $<\mathrm{s}>$ nahasketaren ondorioz, honako hauek ere : gaizo (2), gaizoari (2), gaizotasun (1).

31 - Bokal arteko [j] zaharra bizkaieraren eremurik zabalenean [(d)̌̌ ] ahoskatzen da eta zen. Ahoskera honen lehenengo arrastoak Refranes y Sentencia sen aurkitzen dira. Cf. Mitxelena 1977 : 176-177.

32 - Ik. Lapesa $1984:$ 421-424. 
lo he probado por experiencia (...). La tercera es de las voces que suenan a la $x$ y su pronunciacion Latina, v.gr. a uxe, orixe, guexeago, goxo, y se pronuncian casi a usye, orisye, gueisyea go, goisyo. [DT xxxviii]

Honenbestez, Larramendik $\breve{\mathbf{s}} /$ hotsa irudikatzeko nagusiki $<$ is $>$ nahiz $<$ (i) sy> darabil bai hiztegian bai idazlanetan ${ }^{33}$ (puisca AS ; maisucariac, choraisca Cor. ; bereisquiro Cas. $H H$ "distintamente" : berezquiró etab.) eta $\langle\mathrm{x}\rangle-x e$ indartzailean ia bakarrik (orixe, alaxe etab.) baina hau ez da beti $\langle\mathrm{x}\rangle \mathrm{z}$ agertzen, Andoaingo sermoian ausyé eta Burgosko Dotrinan arasye ere aurkitu baititugu. Markatzekoa da, bada, goian ikusi ditugun arex, lexar etab.ek ez gaituztela ipar-ekialdeko hiztunen edo hizkeraren baten aurrean jartzen.

Kardaberazek ere bere kezka agerian uzten du, hainbat proposamen eginez (Eusqueraren berri ona c 23-25) : $\langle\mathrm{x}\rangle$ euskaratik baztertu ; / x/irudikatzeko $<\mathrm{g}\rangle$ erabili : "g edo gea orren lecuan badegu : ta efaten dan bezala e $\int c r i b i t u$ bearda : Egemplo, Egercicioa, Egercitua..." (Ikus $<\mathrm{j}>$ behean) ; $\mathrm{ks} /<\mathrm{g} \boldsymbol{\int}>\mathrm{z}$ nahiz $<\boldsymbol{\int}>\mathrm{z}$ idatzi eta $\breve{\mathbf{s}} /<\boldsymbol{\int}>\mathrm{z}$ adierazi. ${ }^{34}$ Hainbat lanetan, halere, $<\mathrm{ss}>$ darabil, 1762 edo inguruko dotrinan : elessa $(28,29)$, elessa co $(14)$, guessoac $(45)$; Egerc. I : issill $(316)$ ; 1783 ko dotrinan < is > ageri da : elisa $(37,42)$, elisa co $(14)$, elisa ra $(62)$, ga iso (64), halaber, Christavaren bicitzan (1760) : guistocoa (146) eta $\langle x\rangle-x e$ indartzailean : Alaxic $(1744 ?, 96)$, orrelaxe $(1744 ?, 183)$.

$$
<\mathrm{j}>,<\mathrm{g}>\text { : }
$$

Jabe (1, 2, 3, 6), jai (1), jaio (1, 2), ja nean (2), janzi (1), jaqui (1), jaquituria (3, $8)$, jaquindunac (2), ja quiten (2), jarraicen $(1,2,3)$, ja rriric $(2,9)$, ja so $(1,6,8,9)$, ja socea (2), ja usi (1,3), Ja inco (-a ren etab. 3, 4, 6, 7, 8, 9), Ja una $(1,2,3,6,7,8,9)$, Ja ungoicoa (-ac etab. 1, 2), ${ }^{35}$ joan $(1,2,3,4,5,6,9)$, jocoan $(1,2)$, josi $(1,3,9)$, etab.

$<\mathrm{g}>e$ eta $i$ aurrean :

Evangelioan (3), Evangelioaren (8), evangelioco (9), Colegiora, Monge (4), Vrgina (2, 9).

Grafia hauen ahoskeraz dela eta, Larramendik eta Kardaberazek / / hotsa berrikuntzatzat ${ }^{36}$ hartzen dute :

La pronunciacion gutural de la $j$, y de la $g$ no es del Bascuenze. Verdad es, que en algunas partes la $j$ consonante se pronuncia muy gutural, como en Romance, ja una, ja n, jo, a na gea \&c. pero es pegadiza essa ponunciacion; de que es argumento, que no solo en Francia, mas tambien en la mayor parte de los Bascongados de España, se pronuncia como la $j$ Latina, dulce, y no gutural joan, jauna \&c. y es menester guardar la primitiva pronunciacion. [El imposible vencido, 337]

En este dialecto de Guipuzcoa se ha introducido la pronunciacion castellana de la jota gutural y fuerte : Jauna, jo, jatorriz, etc. que es contra la costumbre de todos los demas dialectos, y parece pronuciacion pegadiza [DT xxx]

33 -Cf. Mitxelena 1978 : 394. Lakarra 1985 : 247.

34 - Alabaina, $\breve{s} /$ eta $\$ \mathbf{s} /$ arteko bereizkuntza deuseztatu egiten zuen, Larramendik eta garai hartan ohi bezala, s luzea baitarabil oraingo $<\mathrm{s}>$ aren lekuan. Hona zer dioen Jesus Maria ta Joseren devocioan, zentsuraren aurretik egiten dituen oharren artean : (...) Lo mismo es para ga issoa, a issea, orisse etc., y suple bellamente la vírgula sobre la s para las dos ss, sin i como en $\tilde{n}^{\prime \prime}$. [Cf. Tellechea Idigoras 1990 : 302].

35 - Ja ungoicoa lehen bi eskuizkribuetan soilik ageri da. Gogora dezagun Larramendik Kardaberazi esana : "No se diga Jangoicoaren, sino Jaungoicoaren, porque Dios no es ja na, ez goicoa, ez becoa. Dígase Jaincoa y déjese el Ja ungoico a para quando se pregunte qué quiere decir Ja incoa". [Cf. Tellechea Idigoras 1990 : 304]. 36 - Gerora Añibarrok eta Zabalak bezalaxe, nahiz eta hauek Kardaberazek aholkatutakoari ez zitzaizkion lotu, / $x /$ eta $\not /$ idatziz bereizteko < i z z baliatzea, alegia. Cf. Urgell $1987: 371$. 
Jota Euscararena ezta baicic Erdaratic artu, edo etorria. Euscalerrietan len ia, ie, io, iu usatcenzan : ta orañere Bizcaian ascotan esatenda : ian, iauna, monîa, ta ez jan, jauna, monja : au eransia da [Kardaberaz, Eusq. Berri onac 24] ${ }^{37}$

Larramendik onesten zuen ahoskera idatziz irudikatu nahi duenean, hala ere, $<\mathrm{y}>$ erabiltzen du : "La Pronunciacion de la $j$ gutural, que hay en algunos parajes, no parece del Bascuence, sino pegadiza del castellano, jauna, jan, joa $n$, jo, que en lo general del Bascuence se pronuncian jauna, jan, joan, jo, inclinandose à yauna, yan, etc" [DT xxxviij]. Grafia, hala ere, lehengoan utzi zuen, hitz hasieran nagusi baita $<j>$, nahiz eta gaztelaniaren banaketa (< ge > < gi>) gordetzen duen : ja naria, gela, giratu, jocoa $(\mathrm{HH})$ etab. Badira testuinguru honetan $\langle\mathrm{y}\rangle,\langle\mathrm{i}\rangle$ eta $\langle\ddot{\mathrm{i}}\rangle$ ere : yaroa, iurtzuria 'trueno' (baina iyurzuria 'relámpago'), yocoa (HH-n), ïoriena (Mendibururi egin gutuna), ioriagoric (Andoaingo Serm.). Bokal artean eskuarki $<\mathrm{y}>$ darabil eta beheranzko diptongoetan $<\mathrm{i}>$ :

oyei (Gandarari gutuna), oyetan, a yenatu (Cas.), gaya (AS), sustraya (AS), erra yetaco (AS), sa yetsa (AS), iba yac (AS), leyal (AS), lo ya vs. loi (HH), na ya vs. nai $(\mathrm{HH})$ etab. baina : jaierá (Andoaingo Ser.), a nay (AS), etsaien (AS), gay, gueiago (Mendibururi egin gutuna) etab.

Eskuizkribu hauetan ez da halakorik, < y> diptongoetan aurkitzen baitugu :

Ayta (3), ayrean (1), ayze (8), ay (3), array, goyticoa, goyzean, ibayric, iguy, leyquezu, leyteque, loy, loyturic, oy (3), oytura (3), pozoy, pozoytuac, pozoyz, traycijoa, baina : aizearen (3), Aitazat (2), naiz (1), zein, zeinda, zeinzuec etab.

Bada <y> ren beste erabilera bat ere, hitz hasierakoa: Ygnacijogatic, Ygnacijorena, Ymagina, Ysabel.

ij $\mathrm{V}^{(\mathrm{a}, \mathrm{e}, \mathrm{o})}$ : ez da ageri lehen eskuizkribuetan. Halere, corpus osoa kontuan harturik markatzekoa da azken eskuizkribuetan $(7,8,9)<j>$ ia erabat erabiltzen duela, batzuetan hitz bera gabe ere aurkitzen dugun arren :

Amodijoac (7) /amodioac (2), andija $(5,6,7,8,9)$ / andia $(1,2,3)$, arguijac $(8,9)$ /arguiac (1), arriga rrija $(8,9)$ /a rrigarria $(9)$, beguijac $(6,8,9)$ /beguiac $(2,3)$, bizija $(6,8,9)$ / bizia $(1,3)$, deguijotela (7) / deguiotela (3), demonijoa (8) / demonioa $(1,2,3,8,9)$, demonijoari (8) /demonioari $(1,3,6)$, dijogu $(6) /$ diogu $(2,3)$ erremedijoa $(6,8,9)$ /erremedioa $(1,2)$, gracija (-jac, -jaren, 8,7$) /$ gracia (-ac, -a ren, 3,8), guzija (9) /guzia (1), ibaijan (9) /ibaian (4), iturrija (9)/iturria (3), jaijo (9) /jaio (2), jaijocen $(6,8)$ / jaiocen $(1,2)$, mingarrija (9) / mingarria $(2)$, mingarrijac $(9,5)$ /mingarriac $(2,4)$, negargarrija $(8,9)$ /negargarria $(1,2$, $3,4)$, oracijoan (8) /oracioan (2), salvacijoa $(8,9)$ /salvacioa $(1,3)$, zijon $(6,7$, $8,9)$ / zion $(1,2,3)$ etab.

Grafia hutsean murgilduaz, eta oraingoan corpus osoa kontuan hartu dugun arren, esan behar da honek ere ez gaituela Larremendiren egiletasunaren alde jartzen. Otxoa Arinek, Arzadunek (1731) eta Irazuztak diptongoetan ez eze, bokal artean ere $\langle y\rangle$ erabiltzen dute :

bazayo (OA 74), gueyago (OA 166), zayonetic (OA54); deyozula (A 55), jayac (A 18), jayaqueran (A 15), jayo (A 15), nayaco (A 54); ba ta yatu (I 37), bazayo (I 39),

37 - Hala erabiltzen $\mathrm{du},<\mathrm{i}>\mathrm{z}$, bizkaierazko idazlanetan : Cristiña u Dotrinea (1762 edo ingurukoa) eta Jesus, Maria, ta Joseren devociñoco Libruchoric atararico devociño batzuc (Iruñea 1764). Zernahi gisaz, hauetan ere badira salbuespenak : Jaungoico (C. D. 1762?), jabe, Jaincoa (1764koan). 
doa yac (I 44), doa yen (I 23), gueyago (I 19, 21), ja yotcen (I 13, 36, 40), oguiya (I 23), zayola (I 11) etab.

Bestenaz, $<$ b > idazten du $a$-ren aurreko bokala $u$ denean. Hala ere, zalantzak ageri dira :

barruan $(1,3,6)$ / barruban (1), christauac $(3,5,6,7,8)$ / christaubac $(1,2)$, contuban (1), credituba (6), cuidadua (8) /cuidaduba (1), erreñua (3), estadua $(1,2,8)$ /estaduba (1), ispillua (6) /ispilluba (6), isuan (1) /isuban (1), lecua (9) / lecuba (5), santua $(6,7,8,9)$, tituluba (5) etab.

Inoiz edo behin $<\mathrm{v}>$ ere itzuri zaio : gava (9).

Derradan, azkenik, $A$ bokalari $a$ gehitzean ere $a / e a$ bikoteak ageri direla baina $a$ da nagusi :

santac (9) / santeac (1), criaturac (2) /criatureac (8), Honrrea $(1,3) /$ honrra $(6,8)$, honrran (9), a rimari $(1,3)$ /a rimeari $(2,3,6)$; baina: Aita (bat), Ama (bat 1$)$, Aita ren $(1,2,8)$, dembora $(8,9)$, doctrina $(1,2,8)$, fortaleza, fortalezaren (9), ezpata, ezpata requin (1), gauza, gauzaren (1), ca tholicarenac (1), eriozaren, erioza (1), culpa (1), eliza (1), elizaren (2), ba lanza (7), señora $(1,8)$, templanza (9), Virgina (8) etab.

Hona zer dioskun Larramendik Corografían (301) : "En Azpeitia ondo diala, bia ondo, y en las vecindades; (...). También aitea, amea, damea, señorea, por aita, ama, dama, señora". Ezaguna da, ordea, ezaugarri honek hedadura zabalagoa duela. Larramendik berak Azkoitiko Sermoian ere santea, eriotzea, lotsea, esposea etab. dio baina salbuespenak ugari dira.

E denean ea da nagusi : bidea, emacumeac, emacumearen, emaztea, legueac, libertadea, maitea, nescameac, predicadoreac, semeac, virtutea etab. ${ }^{38}$

Badira bokal bikoitzak ere, gehienbat deklinabidean $-a-z$ nahiz $-e-z$ hasten diren atzizkietan (leku kasuen eta genitiboaren pluralak), hala nola kontsonante baten galeraren ondorioz: aitaac, circunstancijaac, ugazabaac, echeetan, ateetan, a labeen, arimeetan, gorpuceen, beera, etab. Larramendiren idatzietan usu ageri dira : loraa, doloreen, orreec, gaitzbagueena, tristeena, beraa, minberaatu (AS) ; nobleena, hitzcundeetatic, naasi (Mendibururi egin gutuna), urteetan (Gandarari gutuna). Arzadunen 1731ko edizioan: Oneec $(18,43,46,48 ; 1758$ : Onec 23, 49, 53,55 , baina 54 . or. Oneec)

\subsubsection{Azentua}

Corpus osoan ondoko bi hitz hauetan soilik ageri da : cuchá eta baná. Hala ere, adierazgarria dela iruditzen zaigu, alde batetik, B-k idatzi dituelako eta, bestetik, gure susmoak sendotzen dituelako, nahiz eta Larramendik zenbait lan badituen azentu markarik gabekoak ere (Gandarari egin gutuna, Santo Tomás eta San Casimiroren otoitzen itzulpenak, Sobre los Fuerosen eta Corografian diren euskarazko zatiak). ${ }^{39}$

B-k cuchá izena arca-ren ordainetan eman du eta agerraldi bakarra du, A-k arcan, arca ri, a rca tic baitarabil. Larramendik HH-n (I 93) honela dio : 'Arca', (...) cuchá , uchá (...). Baná ere behin bakarrik ageri da : eta dirade baná, edo diferenteac (ik. ondoko atalean).

38 - Kardaberazen $e a, i a, o a, u a$ aldatzen da Tolosako edizioan (1783), ia , ij $\bigvee^{(a, e, o, u)}, u a, u b V^{\nmid a, e, o,)}$ sistema nagusitzen doalarik mende honetan. Cf. Altzibar 1991 : 263.

39 - J. Lakarrak (1995 : 247) Larramendiren idatzietan den alde honen arrazoia bilatzean lehenengoen (Artea, Hiztegia, Sarrera gutuna) nolabaiteko asmo pedagogikoa kontuan hartu beharko litzatekeela uste du. 


\subsection{Morfologia}

Atal honetan adizkietan eta beste hainbat egituratan B-k egin dituen aldaketak azalduko ditugu. Honetarako eta lexikoa aztertzeko ere Loiolako artxiboan den Mendibururen Dotrina eta Burgoskoa ere aurrean izan ditugu, ${ }^{40}$ gure helburua erdiesteko garaian Loiolakoari Larramendik egin zizkion zuzenketak eskuizkribu hauetan B-k egin dituenekin alderatzea bere garrantzia duela iruditu baitzaigu. Nolanahi ere, esan behar dugu ez ditugula orain aldaketa guztiak zehatz-mehatz aztertuko, oinarritzat hemen B-k egin dituenak soilik kontuan hartu ditugu. Ondorioz, zuzentzaileaz edo zuzentzaile bakar batetaz ala egileaz hitz egin behar dugun agerian geratuko dela uste dugu ondoko bi ataletan ere.

\subsubsection{Aditza}

Adizki perifrastikoak : adizki trinkoak edo Larramendik "irregular" deitzen zituen haiek B-k egin duen aldaketarik nabarmenena da. ${ }^{*}$ Ezan : Egin eta zenbait pluraletako formak ere zuzendu ditu.

atravesacen baliz ere A: balijoaque ere B (1)

... lastocho baten valioaren gañean eguiñagatican ere, eta mundu guzziaren honrrea a travesacen baliz ere / balijoaque ere, jaquin bear dezute...

Joan aditzean diala (9) / dijala, dijazala (6) ageri dira 3. pertsonan. Larramendiren Azkoitiko Sermoian : diazenean, diazquit. HH-n (23) : doa / dia / dijoa;doaz /dijoaz/diaz eta diazquit, balijoa.

gorpucera beguiracen duten A: [gorpu]tzari dagozcan B (2). ${ }^{41}$

Bigarren sermoian birritan egin du B-k zuzenketa bera :

- Eguiten dela becatu mortala gorpucera beguiracen duten / [gorpu]tzari dagozcan necesidadeetan (premietan) socorritu, eta a sistitu ez agatican...

- Arima ra beguiracen duten / Arimari dagozcan gauzetan useguinagaticg...

Hurrengoa ere honela zuzendu du B-k :

Umeai demporaz (mugonez) ez emaitea, conveni zaizten estadua / dagocan zucenbidea $^{42}$

Bigarren sermoian A-k berak ere aldaketa hau egin du :

Ba ñ Ja una, guere beca tu a ndi, eta neurri gabeacatican mereci ez badegu ere / ez badoquigu Aitazat berori eduquicea.

Egon nor-nori sailean forma hauek erabiltzen ditu : dagoquijona (dagoquijo), da gocala, dagoquiguna, dagoquiozcan, dagoquien (azken forma hau birritan aldatu $\mathrm{du}:$ dagoquiozcan) :

40 - Ikus Loiolako dotrinaren aitatasunaren auziaz eta P. Altunaren aburua berak paratu zuen Mendibururen idazlan argita ragabeak lanean. Burgosko Dotrina, berriz, J. Lakarrak argitaratu zuen eta Loiolako eskuizkribuarekin eta horri Larramendik egin zizkion eranskin eta zuzenketekin konparatzen du, ezberdintasun guztiak zehatz-mehatz oharretan emanez. Horretarako, P. Altunak egin zituen oharrez baliatu dela ere adierazten digu. Facsimilea eta hiztegia ere eskainiak ditu (ik. Lakarra, 1986 eta 1987). 41 - tzari dagozcan [idatzi du B-k lerro artean]. Necesidadeetan [egileak berak ordeztu du :] premietan. 42 - Umeai demporaz estadua ez emaitea [idatzi du A-k lehenik eta ondoren estadua ezabatu]. Demboraz [A-k berak bigarren eskuizkribu honetan ordeztu du :] mugonez [B-k aldaketa bera egin du, hain zuzen, lehen eskuizkribuan]. 
... zeña bacoizari dagoquijona ematera beti iraulcen da (6) ; Birao ezeri ez dagocala eguinicoa (1) ; cergatican guri dagoquiguna da...(6) ; ...baña baita ezauzen ere det zure odol tanta bat dala asco ez nere becatuai dagoquien / dagoquiozcan ze baita Mundu guzti onetacoai dagoquien / dagoquiozcan sugar ica ragarri guztiac (4); milla infernu da goquiela nere becatuai (4).

Larramendiren idatzietan hauek aurkitu ditugu : dagocan, (Andoaingo Serm., St. Tomas itz.), dagocana (AS, Sarrera gutuna), dagoquionean (Andoaingo Serm.), dagozquizunac (S. Casimiro itz.). Artean (244. or.), berriz, nágoca, ágoca, zágozca, dágoca, gágozca, zágozca te, dágozca dakartza (Azentu markarik gabe HH-n I 351, baina hemen aspektu eta pertsona guztietan osatzen saiatzen da). Burgosko Dotrinan dagozcan, badagoquio, dagozquionac aurkitu ditugu. Hemen ere -ri dagozcanac ageri da $(7,8)$ baina Mendiburuk Loiolakoan Jaincotasunari datozquionac ; Guizatasun Santua ri da tozquionac idatzi ondoren Larramendik zuzendu zituen : dagozcanac.

Larramendiren idatzietan eta $H H$-n ageri den dagozquio forma eskuizkribu hauetan dagoquiozca moduan emana da, goiko zerrendan ikus daitekeen gisan.

Nor sailean : dago (1..., dagoan $1,3,6$; dagoala $1,2,3,6,8)$, zagoz $(8$, ba zagoz 4, zagozela 6), dagoz $(2,6) /$ dagoza $(1,2) /$ dagozte $(1)$; nengoan $(9)$, zegoan $(2,3,5,6,8,9$, bazegoan $2,6,8,9)$, zegozala (2, zegozela -haiek-)

Hemen ere aldaketa batzuk badira Larramendiren gramatikatik hiztegira, eta gehienak pluraleko formetan gertatzen dira: nágo (1729) /nago (1745); ágo /a go ; zágoz, záude /za goz zaude ; dágo / dago ; gágoz, gáude /gagoz, gaude ; zágoze, záute / zaute, zaudete ; dágoz, dáude / dagoz, daude. (Lehen. :) néngoan / nengoan ;égoan /engoan ; cégozan, céunden / cengozan, ceunden; cégoan / egoan cegoan; guégozan, guéunden / guengozan, gueunden ; cégozaen, céundeten /cengozaten, ceunten, ceundeten; cégozten, ceuden /cegozan, ceuden.

Dakusagunez, testu hauetan iraganeko 3. perts. pluraleko forma, zegozan (-la), Larramendik hiztegian jasotzen duenarekin doa.

Bidenabar esan dezagun aditz erroa eta atzizkia lotzen dituen bokala a dela nagusi, $e$ dutenak ere badiren arren : dagozen (2), dagozenean (2), bazenuen (1), zaituen (9), debenac (1), zagozela (6), zegozela (2).

$\Rightarrow$ jarraizen zaizte A: badarraizca B (2)

... ta Seme gaizto oei jarraizen zaizte /badarraizca Jaungoicoaren madaricacioa.

Aditz trinko hau A-k ez du inon erabiltzen. Larramendiren idatzietan :

Darraizcun (Corografian, 320-321) darraizcánac (Sarrera gutunean), darraiztenac (AS).

$\Rightarrow$ dedaz $\mathrm{A}$ : ditut $\mathrm{B}(1)^{43}$

Birritan ageri da dedaz lehen eskuizkribuan eta bigarren agerraldia zuzendu du B-k.

dezuz: dituzu $(1,2$. Dezuz formak hamar agerraldi ditu eta bakarren bat izan ezik, beste guztiak zuzenduta daude. Bi sermoi horietatik kanpo dituzu darabil). Halaber, dezuzanean: dituzunean.

Aldaketa adierazgarriak badira ere, hona hemen darabiltzan beste forma batzuk (sing. Corpus osoan) $)^{44}$ : det /dut; badeu /du ; degu ; dezu / dozun ; dezue /dozuen /dezute/dozuten; debe /dute. (Azken hau honela aldatu da

43 - dedaz [ezabatu eta alboan B-k :] ditut

44 - Hemen ez ditugu forma guztiak emango, ikerlan zabalago batean aztertzen ditugu. 
lehen eskuizkribuan : falta tu oi debe / useguin oi dute).

(plur. :) dedaz (2 aldiz, 1 sermoian) /ditut (5 aldiz)/dituztadan; ditu; ditugu

/deguz; dituzu /dezuz; dituzute /dezutez; dituzte / ditue.

$\operatorname{Dozu}(n)$, dozue (n) eta dozute (n) agerraldi bakanak dituzte, dozuen birritan eta besteak behin bakarrik, guztiak lehen eta bigarren eskuizkribuetan. Halaber, objektoaren aniztasuna isladatzeko $-z$ ere badarabilela amaieran dakusagu. Bestalde, $-e u-3$. pertsonan orainaldian soilik darabil, zuen eta zuten formak erabiltzen baititu lehenaldian ; gainera, agerraldi kopurua oso urria da : badeu behin /du 100 aldiz; debe 11 (atzizkiekin) /dute 75 (atzizkirik gabe). Beste formetan ere luque, luquean, nuque, nuquec, balu, etab. ditugu. Nagusi dira, bada, $d u, d u t e, d e z u$, dezue etab. formak. Nolanahi ere, esan behar da - eu-dun adizkiak gizpuzkera zahar ia osoak (Otxoa Arinek, Irazuztak, Zegamako dotrinan, Larramendik) erabiltzen dituela : deb /debe / dabe /deu, ceban / ceben (OA) ; deb/debe /deub, cebean /zuen (ZD); du/deb, zuen /ceben (IR), deu, deue, baleue etab. (Lar. AS). Haatik, Goierriko testuetan $a$ eta $e$ ondoren aurkitzen diren $(u) b$ formak $(d e b$, deub, la $b, l a u b .$. ) ez dira aztertzen ditugun eskuizkribuetan ageri.

$\Rightarrow$ dide A : didee B (1. desesperatu eraiten dide : burutic ja usi eraguiten didee).

Didee behin bakarrik ageri da, B-k idatzia, hain zuzen ere. Dide, berriz, hiru aldiz darabil A-k eta guztiak lehen eskuizkribuan. Lehenaldiko forma ez da ageri. Larramendik Artean (91. or.) : didate / didee ; cidaten / cideen. Gandarari egin gutunean darabil didee forma : ala esan oi didee nacustenac.

Eskuizkribu hauetan orainaldian beste forma hauek aurkitzen ditugu :

Dit, diote / dijote, digute, dizute, diot / dijot, diogu / dijogu, diozu / dijozu, diozute, zinion, zioten etab. (Plur. :) diozca / dijozcala ("dizkio"), diozcaten ("dizkioten"), diozanari, dioztet ("dizkiet"), diozten, dioztezu ("dizkiezu"), ziozcala, ziozcaten formen alboan -rauz-ere baditu : badirauzcazu, dirauztazun, zirauzun eta -zki-dunak ere ageri dira : dizquidan, dizquizuen, zenizquigula, zizquigula etab.

Beraz, polimorfismoa nabaria da. Alabaina, Otxoa Arinek, Irazuztak eta Larramendik ere dio- eta dira uz- formak batera erabiltzen dituzte, -zki-dun formarik agertzen ere ez delarik : Larramendiren Azkoitiko Sermoian ciozcala baten alboan, -rauz-dunak dira pluraleko forma bakarrak. Otxoa Arinek eta Irazuztak, berriz, dira utza, cira uzcan etab. formen alboan, usu erabiltzen dituzte diozca, ciozcan etab. Otxoa Arinen Dotrinan, bestalde, die forma bakarra aurkitzen dugu nor sing. eta pluralean ("die", "dizkie"). Honek guztiak gipuzkeraz dio - formak ez zirela eta ez direla bakarrak adierazten digu.

$\Rightarrow$ dezadala A: daguidala B (1).

emon dezadala / daguidala. Lerro pare bat beherago aldaketa bera egin du B-k : la gundu dezadala / daguidala. ${ }^{45}$

A-k berak dezaiogula deguiogula aldaketa egin du bigarren eskuizkribuan : Ala ere emendic aurrera deitu dezaiogula /deguiogula Aitaren izenaz. ${ }^{46}$

Eguin laguntzailearen beste forma hauek aurkitzen ditugu :

ez daguiala eraman (9. eskuiz.), erreciuitu daguizten (2), ez zaguizala azeratu (8an), la rga deguiola (3), jarraitu deguiogula, jarrain deguijotela (7, era man dezala

45 -Larramendik Azkoitiko Sermoian aldaketa hau egiten du : Eguin diozagun Daguiogun. 46 - Lehenik izenarequin idatzi du. 
bere gurucea, ta jarrain deguijotela), sepultatu zeguiela (1), esan zeguijola (9) etab.

Otxoa Arinen dotrinan, Zegamakoan, Larramendiren Azkoitiko Sermoian, etab. ere egin laguntzailetzat aurkitzen dugu.

\section{$\Rightarrow$ Eguin ezazu contu A: eguizu contu B (1)}

Aginteran A-k*ezan aditz laguntzailea darabil : ezazu, eza da zac, ezazuz, ezazue (birritan ezazute formaz aldatu du A-k), ezazute, ezadazu, ezaiozu. Egin adizkiaren forma bakar hau, bada, B-k idatzia da. Ezazu formak dituen beste agerraldietan aditu eta $a$ si aditzen ondoan ageri da. Ezazute : aditu eta jaquin eta ezaiozu ere aditu aditzaz darabil (Ik. jarraian besteak).

Era berean, Esan ezadazu A: esadazu B (1).

Hurrengo orrian ere B-k zuzenketa bera egin du. A-k ere badarabil, ordea, aditza eta forma laguntzailea elkarri itsatsita ; gainera, bost aldiz $\langle\mathrm{z}>\mathrm{z}$ idatzi du : ezada $z u$ (hiru agerraldi zuzendu ditu : $z$ s); beste zortzi agerraldietan : esa dazu. Esadazute ere lau aldiz ageri da eta birritan ezadazute (Ik. grafian 2.1.1).

Larramendiren Corografian (301) honela irakurtzen dugu : “En Azpeitia (...) y también barruan, barruna, a ujaz, a usaz, eman eguidazu, esan eguidazu, por indazu, emadazu, esadazu ; aunque en Azpeitia y Tolosa se entienden bien los diversos modos de hablar". Mendiburuk Loiolako Dotrinan ere esan zadazu (12) idatzi ondoren, esa dazu jarri zuen Larramendik. Era berean, Esa nitza tzu : Larramendik Esa itzu $(30,31)$. Burgosko Dotrinan (1747) ere hala ageri dira, esa dazu eta esa itzu, alegia. 25. pasartean ere esa dazu ageri da dotrina honetan baina Mendiburuk Loiolakoan esa zu idatzi zuen.

$$
\Rightarrow \text { a itatu ezazuz A : itzatzu B (1) }{ }^{47}
$$

Hemen ere $-z$ pluralgilea amaieran darabil, *Edun-en formetan ikusi dugun gisan. Eza zuz formak hiru agerraldi ditu eta hirugarrena zuzendu du B-k ; itza tzu-k, berriz, bakarra, B-k idatzia, hain zuzen ere. Guztiak lehen eskuizkribuan ageri dira. Larramendik Artean : ezazu, itzatzu.

\subsubsection{Beste egiturak}

$\Rightarrow-(a) r e q u i n$ A : -(e)an B (2 eskuiz.)

...araco Seme, icusi eta aurquiturican eren Guraso tristeac necesidade (premia) andian ${ }^{48}$ nola gaixoric dagozen demporan, edo zarturican, socorrizen ez dituenac Ja tecoarequin, eta Janciarequin...

Honela aldatu du B-k : asqueneco(sic) premian, bearrean, etsi etsian, ja nean, edanean eta jaztean. ${ }^{49}$

Lehenik esan behar da, necesidade hitzaren ordainetan ageri den premia A-k berak idatzi duela baina B-k aldaketa bera egin du, hain zuzen, lehen eskuizkribuan (ik. beheko esaldia). Bestalde, maiz darabil A-k soziatibo-atzizkia $-z$ instrumentalaren ordez, ondoko esaldian ageri diren zuzenketak honen lekuko direlarik:

... juramentu eguin bear danean, eguin dedila necesidadearequin edo provechuarequin, devoziarequin / devozioz, fedearequin / fedez, eta reverenciarequin / reverenciaz (1 eskuiz.).

47 - ezazuz [zuzentzaileak orriaren ertzean idazten du :] itzatzu 48 - andian [premia rekin batera egileak lerro artean idatzi du].

49 - asqueneco[sic] premian, bearrean... eta jaztean [orriaren ertzean idatzi du B-k]. 
B-k necesidadearequin : premiarequin aldatu du.

A-k seigarren eskuizkribuan ere honela dio : fede bizijarequin, ta devocioarequin. Bigarren eskuizkribuan, berriz, aldaketa hau egin du izena requin : izenaz (cf. goian dezadala sarrera).

Mendiburuk dotrinan ere Oracio, ta humiltsunarequin idatzi zuen eta Larramendik honela aldatu : Oracioz ta humiltasunez (41). Burgosko dotrinan ere hala ageri da. Larramendiren testuetan ondokoak aurkitu ditugu :

... guztiac dirade biotz nóbledunac, hónraz, leialtadéz, prestutasúnez, christáu ónen fedez beté betéa c... (Andoaingo Sermoia), garaitasun osoaz (Cas.) ${ }^{50}$

$\Rightarrow$ consequencia seguicen diranacatican A: ondoren datozenacgatic B (2)

...cergatican esa utu gabe ascotan eldu oi diran becatu mortal izaitera, edo ocasio gaiztoagatican, edo consequencia seguicen diranacatican /ondoren da tozenacgatic ${ }^{51}$

Hemen ere aditz trinkoa darabil B-k. Eskuizkribu hauetan forma hauek ageri dira : bada tor, da tor, da torquiozan (datozkion).

Beheko zuzenketan ere -agatican dugu : tristuraric ez emaiteagatican (aditz izena + -agatican). Ikus, halaber, ondoko pasarteetan (cergatican, ezquero, cerren...) :

a visua u emaiten ez diotenac, interes dollor bat ez galduceagatican (2) cergatican oec bezelaco Seme infameac (...) artu izan oi dute (2) cergatican juramentu eguite orduan ez zenuen uste izan zala ala (1) Orra zergatic Jaincoac eguin izan zuen castigu icaragarri ura Emacume zori gaiztoco argan (3)

Bada orregatican beragatican, esaten dizu Ja ungoicoac (...) quenduceco (2)

Guzziraco nezu guertu, zuen oneraco dan ezquero (1)

(Cerren 8. eta 9. eskuizkibuetan soilik ageri da :)

cerren a urquicen ziran triste, (8)

cerren jan orduco bota eraguingo dijon. (9)

$\Rightarrow$ tristuraric ez emaiteagatican $\mathrm{A}:$ da mu eraguiteag[atic] B (2) ${ }^{52}$

... eta gueiago araco Seme eren Gurasoai demporaz (mugonez) avisuau emaiten ez diotenac, interes dollor bat ez galduceagatican, edo tristura ric ez emaiteagatican / damu eragiteag[atic].

Eragin aditza ere badarabil A-k, gehienetan partizipioaren ondoren :

alde eraguiten (1), ze desesperatu eraiten dide (1), pagatu eraguingo ziola (2), Jaincoagandic alde eraguingo digutenac (7), Eguija a u ondo confesa eraguiten dije condenatuai (8), Emen Demonioac sinistu eraguiten dijo becatariari, (8), a serratu eraiten diozten guzzien contra (1) etab.

Damu ere maiz ageri da : nola damu degun, damu dezu, becatuen damu

50 - Honela dio Artean (9. or.) : "En el mismo genitivo ay otros dos articulos especiales, que aunque corresponden al de Castellano, no significan posesión, y mas parecen del ablativo : estos son $z$, ez". (11. or. :) "Tambien sirve al ablativo con frequencia el articulo $a z$, y es posposicion, que corresponde à la preposicion de ablativo con".

51 - B-k goian, lerro artean idatzi du.

52 - emaiteagatican [parean, behean :] damu eraguiteag [idatzi du B-k, atic guk erantsia]. 
(askotan dio), damutu (1) etab.

Larramendik Azkoitiko sermoian honela dio : Cein guichi hura triste icusi ta tristatzen, hura damuturic icusi ta damutzen diranac!; miñez, da muz ; bere miñac, damuac, ta doloreac; Nolaco damu ta naigabeac; cerez mindua, ezpada oña-cez, a tsecabez, damuz; ?("damu artu":) ta cembat damu artu cenduan a ren eriotzean?; alde eraguiten; eraguin daguion negar neure biotz oni etab.

Ikus ondoko aldaketa ere :

$\Rightarrow$ Sacramentu Santuac erreciuitu daguizten A: eleizacoa eraguiteco B (2) ${ }^{53}$

Ala eguiten dute becatu mortala, (...) a raco Seme, eren Gurasoac eriozaren pelliguruan dacustezenean, confesatu ditezen, eta Sacramentu Santuac erreciuitu daguizten / eleiza coa eraguiteco ${ }^{54}$

Bestalde, A-k eliza (-co,-ren...) forma darabil, eleiza-k agerraldi bakarra duelarik, B-k idatzia. Larramenik HH-n (II 2. or.) bi formak ematen ditu eta hala erabiltzen bere idatzietan. Zernahi gisaz, eleiza gehiagotan ageri da : Azkoitiko sermoian, esate baterako, 6 aldiz darabil eta guztietan eleiza dio. ${ }^{55}$ Andoaingo sermoian, berriz, birritan ageri da eleiza eta eliza hiru aldiz. Loiolako artxiboan den Mendibururen Dotrinan Eliza ageri da, haatik, Burgoskoan Eleiza (20).

$\Rightarrow$ orrez conforme / batera A: orren erara eraz B (1)

Cergatican zere aho gaizto orrez batera /orren erara eraz, (...).

A-k ere conforme ezabatu eta gainean batera idatzi du : aho gaizto orrez batera.

B-k orrez gainean orren jarri du eta alboan : erara eraz.

Hurrengo orrian honela irakurtzen dugu : espiritu santuaren sentenciac iracasten duenez conforme eta aurrerago : Evangelio sagraduac iracasten digunez conforme, azken honetan ere conforme ezabatu eta batera-z ordeztu du A-k. Beste honetan berriz, ez da inolako aldaketarik egin : esan nai du, becatariari bere becatuen neorriez conformezco castigu andiac izzaroten diola. Haatik, bigarren sermoian honela dio (-en -z batera) :

Eta ez da ansi zuc eta zuc esa tea, Justiciacg legueaz batera...; eguingo dezu chit ondo zere Gurasoen borondateaz batera governacean; mereci badu Jesuchristoren sentenciaz batera, errota arri bat samatic duela isa sora botacea; Chimijoac, Plinioc escribicen duenez batera, dira abere bazuec eren Umechoac maitecen dituztenac a enbeste, zeinda...

Hirugarrenean ere -z batera darabil : Gracia au, Theologuac dijotenez batera.

Baina : guere Jaungoicoac esaten digun bezela (2), Santu glorioso onec esaten duen bezela (2), beste aldetican izanagatican ere gauzea zuc esaten dezun moduan (1) etab.

$\Rightarrow$ emen illic guelditu nadila A: bertan il nadilla B (1)

Bederatzigarren eskuizkribuan, berriz, honela dio A-k : neguan illic guera ez dedin. Ondoko multzoan ere -rik forma darabilela dakusagu aditzondo bilakatutako partizipioetan, gero ia erabat nagusitu zen -ta edota - $a$ ren lekuan (jarrita, galdua egon

53 - eleiza coa eraguiteco [B-k orriaren ertzean idatzi du].

54 - Larramendik HH-n (120. or. :) 'Obligar a hazer algo', eraguin, a razo, a raci.

55 - P. Altuna \& J. Lakarra, Manuel Larramendi : Euskal Testuak 47. orrian ageri den Elizarequin hutsa da, Eleiza requin irakurtzen dugu guk eskuizkribuan. 
etab.). Egon, guelditu, uzzi, eduqui eta beste bakarren baten osagarri gisa agertzen dira : dagoz obligaturic (2), zegozela jarriric leseriric (2), dagozte oyturic (1), josiric guelditu (1), eroituric uzzi (1), josiric efini (2), escribituric dauzcazan (1), a puntaturic eduqui (1), eseguiric efini (1), obliga turic guelditu (2) etab.

Bestalde, A-k aditz nagusiaren partizipioa erabiltzen du baina baditu, aurreko guera ez dadin bezala, libra zaiza la, libra nazala, la gun zadazu, etab. Aditz izena, hala ere, partizipiotik sortzen du maiz : sartucen, salducen, sortucen, artucen, quenducen (birritan dago zuzendua lehen eskuizkribuan : quencen) uzzizen (utzi-), a sicen etab. baina : iracasten (1), icasten (2), irabazten (1), icusten (1,2).

Mendiburuk ere dotrinan bedeicatudezaten (26) idatzi ondoren, Larramendik tu ezabatzen du eta hala ageri da Burgosko dotrinan ere : bedeica... dezaten.

Bestalde, 8. eskuizkribuan diren ofendidu eta inquietadu agerraldi bakanen ondoan, -tu marka darabil partizipioetan : ofenditu (4 aldiz), pensatu, libratu, barcatu, errezatu, amatu, izentatuco, juzgatu, luzatu, etab.

Berta $n$ aditzondoa, berriz, beti aposizioan ageri da :

illic an bertan guelditu zan (1); su a rtan bertan (1); ordu onetan bertan eldu zan (1) ; puntu artan bertan (3) ; eta onetan bertan dagoala (3); eta ona non gau artan bertan (6) etab.

$\Rightarrow$ iñolaco modutan ere A: iñolaz ere B (1)

jaquin ezazue (ezazute) guzzioc, onelaco juramentuac cumplicera ez dezuela (dezutela) obligaciorican iñolaco modutan ere / iñolaz ere.

Seigarren eskuizkribuan iñola ere darabil A-k. Larramendik ez dakar moduta $n \mathrm{HH}$ $\mathrm{n}$ : "De ninguna manera", iñola ere, iñolaz ere, nihola ere, niholaz ere, iñola mbere. "De ningun modo", iñola, iñola ere, iñolaz ere, nihola, niolaz ere.

Beste aditzondo hau ere ageri da : iñondic ere. Icusirican (...) munduco zuzenbideric inondic ere ez zuela... (6)

$\Rightarrow$ eguinac izanagatican ere A: badira ere B (1)

Aldaketa hau egin du A-k bigarren eskuizkribuan : mereci ez badegu ere Aitaza t berori eduquicea / ez badoquigu. Hona beste adibide batzuk :

izanagatican ere zazpi urte baicen guchiagocoac, (2)

Besteac jaquinagatican ere, (2)

luzaro gozaceco ez baziran ere, (2)

escacen zioten arren (3)

$\Rightarrow$ zeinzuequin $\mathbf{A}$ : ceñaquin $\mathbf{B}(\mathbf{1})^{56}$

Biraoa ezta beste gauzarican, baizic esatea izen bazuec, zeinzuequin / ceñaquin opa zaizcan...

Ondoren, bigarren eskuizkribuan, zuzenketa hauek ageri dira A-ren eskutik : zeinzuec zeiñac.

... dagoz obligaturic Semeac iru gauza gordecera, zeinzuec / zeiñac dirade (dira) a modio... (2)

56 - zeinzuequin [ezabatua dago eta ez da garbi irakurtzen. Bazterrean :] ceñaquin 
Seme buru zenzun baguezcoac, zeinzuec / zeiñac icusirican beren Aita tristeac edo (...) ezertaraco (ere) ez dagoala /dagozala (2)

Esaldi mota hauek hemen ez ditugu aztertuko baina izenordain honen erabilera dela eta, pluralean beti zeinzuec (-equin, -en) darabilela dakusagu :

... Uso, ta Bela, zeinzuec dira penitencia eguiten duenaren, ta urrengo eguneraco largacen dutenen simbolo, edo ezaungarriac.(9)

... ezta guziago Emacumetan, zeinzuen artean izan [...] du costumbre ga izto onec... (1)

... izan ziran necio bazuec, zeinzuec edo Jaincoa tentacerren, edo cerren pensacen zuten ez za la ... (9).

Otxoa Arinen eta Zegamako dotrinetan, esaterako, ceñ-ageri da :

regla aez campora, ceña c arquitcen diraden... (OA8)

pregunta aec, ceñac digeacen eguinican... (OA)

Zazpi peccatu capitalac, ceñay deitcenza tea n... (ZD 66)

Ikus zeña (-ri, -requin...) ondoko pasarteetan (sing.) :

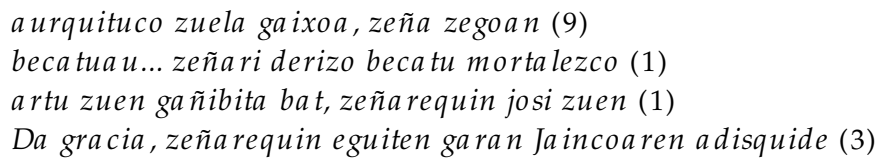

Grafiari begira, bestalde, ceñaren baten alboan, < ze-> da nagusi izenordain honen idazkeran, goiko adibideetan ere ikus daitekeen gisan :

aizearen indarrac bota zuen onzia aizarribaten aldera, ceñaren contra jo zuen onziac (3)

Bustidurak aztertzean ikusi dugunez, Larramendik Kardaberazi eta Mendibururi ceiñ, ceiña idaztea gomendatzen die, eta ez ceñ. Orobat, Artean ere honela irakurtzen dugu (35. or.) : "El pronombre relativo, que como tal sirve, atando una oracion con otra, es ceiñá, ceiñác (...)".

$\Rightarrow$ jaquin bear dezute estadu arcearen gañean gauza bi guztiz diferenteac a urquicen dirala $\mathrm{A}$ : eta dirade baná, edo diferenteac B (2)

B-k egin duen aldaketaren ondoren, honela irakurriko genuke : jaquin bear dezute esta du arcearen gañean ga uza bi aurquicen dira la eta dirade baná, edo diferenteac

Baná azentu marka eta guzti idatzi du B-k (Ik. honetaz lehen atalean). Ondotik aldaketa hau ageri da A-ren eskutik : oe apartecoetan / ba nacoetan.

Hona hemen Larramendik Mendibururen dotrinan egiten duen zuzenketa :

Mendiburuk : “Da Jaincoa bera, Aita, Semea eta Espiritu Santua, hiru Persona ba nac, edo distintoac" (15)

Larramendik : bana diranac.

Burgoskoan ere honela irakurtzen dugu : hiru persona bana diranac. Aldaketa bera ageri da hurrengo (16) pasartean.

B-k egin duen aldaketan, bestalde, dirade irakurtzen dugu. Mendiburuk ere dirade idazten du aurrean aipatu dugun Loiolako dotrinan $(7,16)$, baina -de ezabaturik dago. Burgoskoan, ostera, dirade irakurtzen dugu baina ez beti, dira ere ageri baita $(41,42)$. 
Honaino egindako azterketan mugaturik ere uste dugu esan daitekeela Larramendi ez dela eskuizkribu hauen egilea. Honen egiletasunaren aurkako aztarnak sail guztietan kausi ditugu, baina grafian bertan ere gera gaitezke $(<\mathrm{c}\rangle,\langle\mathrm{z}\rangle,\langle\mathrm{s}\rangle$, azenturik eza, $<\mathrm{h}>$ ri buruzkoak etab.), lehen atalean erakutsi dugun eskua bera ahaztu gabe. Izan ere, grafiari gagozkiolarik, Larramendik teorikoki egin zuen lanaz gainera, grafi sistema aski bateratua eta hein batean berritzailea garatu zuen, bere idatziak inorenetik bereizteko adinakoa. Ez dugu hemen alor hau xehe eta zabal aztertu, baina A-ren jarrera ez dela Larramendirena esateko adina froga badela uste dugu. B-rena, aldiz, bat datorrela baiezta dezakegu $(<\mathrm{tz}>,<\mathrm{ts}>$, azentua, $<\mathrm{h}>$ aren erabilera etab.). Are gehiago, ene lanaren azken atal honetako hitz zerrendari aski da so arin bat egitea Larramendiren eskua non den antzemateko.

Beste hainbat ondorio ere atera daitezke, baina gure helburu mugatuaren kariaz ez ditugu orain azalduko. Segidan aurkezten ditugun hitzen jarraipenean eta azterketa zehatzetan ere ez gara murgilduko, aurrean esan bezala, testuko agerraldiak Mendibururen eta Burgosko dotrinan direnekin erkatzeari aski dela baiteritzogu oraingo gure asmoa betetzeko. Esan beharrik ere ez dago hitz guztiak ez ditugula horietan aurkitu, batez ere edo oro har ezkerreko aldean ageri direnak. Atal honetan, bestalde, corpus osoa kontuan hartu dugu eta zifrak hitzaren sarreran izan ezik (eskuizkribuari dagokio), agerraldi kopurua adierazten du.

\subsection{Lexikoa}

afectoetan A: gogoetan B (1)

Arimaren barruco afectoetan/gogoetan.

Afecto (6), afectoetan (1). Gogo (35), gogoa (12), gogoac (2), gogoan (4), go goaren (2), gogoarequin (1), gogoeta (9), gogoetac (2), gogoetaz (1), gogoeten (1).

Azken eskuizkribuan honela dio :

Orain jaquingo dezu David santuac Jaincoari eguiten zijon erregu bat: escacen zijon afecto andijaz.

Afecto 5. eta 7. eskuizkribuetan, berriz, gogo hitzaren alboan ageri da :

bear ditu sugetatu guere afecto gogo memorija entendimentu, vorondate (...) (5) ; Jaincoaren gracija ren batean guere naija, guere inclinacijoac, guere gogoeta, ta afecto lurrerunz beguiracen dutenac (7).

Lehen eskuizkribuan deseo hitzaren ondoan darabil :

eztago bada dudarican, deseo, edo gogo isuangoori (...) ;

Larramendiren HH-n : 'Afecto, movimiento, de el corazon', gogoa, biotziguintza . Euska ra-Gaztela nia hiztegian ere gogoa, 'afecto, pensamiento' dakar. ${ }^{57}$

Burgosko Dotrina n gogo hitzak 3 agerraldi ditu : Obra, ta gogo (3) ${ }^{58}$; eguite, ta gogo (11) ; gogo vicia, a smo indartsua (36). Azken honetan Mendiburuk Loiolakoan (...) gogo, edo propositua requin (...) idatzi zuen baina gogo, edo ezabaturik dago.

57 - Loiolako Artxiboan den eskuizkribua eta Patxi Altunak argitaratua erabili ditugu (ik. Altuna 1967). Hiztegi honen papera aztertua dugu eta bertan ageri diren ur markek Larramendik 1742an eta 1743an Biarnon ekoitzitako papera erabili zuela adierazten digute. Paperaren azterketa honek 1743an (ez lehenago) hasi zela euskara-gaztelania hiztegiarekin erakusten digu. Ikus zehaztasunak, nahi izanez gero, gure "Paperaren ur markak" lanean (cf. 2)

58 - Mendiburuk Loiolakoan Obra ordez, eguite idatzi zuen ; halaber, bigarren agerraldian (11. or.). 
amenazazea A: meachatu B (2).

Mea chatu : agerraldi bakarra, egileak beti a menaza / a menazo baitio :

amenaza, amenazacen, amenazazea, amenazazen, amenazo, amenazoac, amenazocen, amenazoren, amenazotic, amenazoz; amenazA lehen eta bigarren eskuizkribuetan darabil eta amenazO (-ac, -ren...), berriz, bederatzigarrenean.

HH-n : 'Amenazar', meachatú, queinatú.

antoxu A: guraria B (2)

... baicic eren naia, eren antoxu / guraria, eta a petitua.

Agerraldi bakarrak. Alabaina, naiqueria hitza ere badarabil egileak ; ez, ordea, naicundea. Naiqueriac (2), naiquerien (2) :

Oen naiqueriac izan bear oi debe eche guzzico legueac (birritan 2. eskuiz.)

a si ezazu naiquerien artean, (2. eskuiz.)

Aurchoac naiquerien artean (2. eskuiz.)

HH-n : 'Antojo', guraria, zalea, guticia, naicundea.

Burgosko Dotrinan gurari 5 aldiz ageri da: Besteac gallentzeco gurari erabagueco bat 39 (2), gurari eragabeco bat 40 (3). Mendiburuk Loiolakoan lehen agerraldian soilik dio Gurari : gurari ordena bagueco bat; besteetan : gaitz gura ordena bagueco bat; gaitz gura desordenatu bat. Larramendik beste aldaketa batzuren artean, gurari errebela tu bat (errebela tua) idatzi du.

arca A: cuchá B (2).

Lerro batzuk beherago arcan irakurtzen dugu eta ez da ordezkatu.

Cuchá izenak agerraldi bakar hau du, azentu marka eta guzti (Ik. azentuaren atala).

Arca, 5 aldiz ageri da 8. eta 9. eskuizkribuetan; arcan (2. eskuiz.), arcari (8 eskuiz.) eta arcatic (9. eskuiz.) agerraldi bana dituzte.

HH-n : 'Arca', (...) cuchá, uchá (...).

atencio $\mathrm{A}$ : arreta $\mathrm{B} .(1)$

Lehen sermoian B-k bi aldiz egin du zuzenketa bera.

Bigarren sermoian, ordea, egileak berak aldatu du birritan ere :

Ala a tencio / arreta Ja ungoicoaga tican, Christa ubac (Guraso zenzun gaveac), a tencio / arreta guzioc.

Hirugarren sermoian biak segidan idatzi ditu :

Adi zazute arretaz, eta a tencioarequin.

Arreta hitzak 5 agerraldi ditu eta lehenengo biak B-k idatzi ditu. A-k goiko bi erabilera horietatik at cuidadu hitzaren ordainetan eman du bigarren eskuizkribuan. Cuidadu, halere, ardura -z ere ordeztu du.

Atencijo forma ere badarabil ordeztu gabe 8. eta 9. eskuizkribuetan (atencijoan, atencijoz) : 
Guztija ocupaturic bizi izan zera gorputz orren atencijoan?(8).

Adi zazu ta a tencijoz repara zazu; contuz ta a tencijoz (8)

Aplica zazu atencijo orijen bide ta diligencietara (9).

HH-n : 'Atencion', árreta, oa rra, oa rcuna, oarrera.

'Cuidado', a rdurá, a jo lá, a rtá, a ntsia. (Ik. behean casurican : a jola)

vanidadez A: andiustez B (2)

Laugarren sermoian egileak berak testuan txertatu du :

...eta icusico degu, an sobervioac (eta andiustez betericoac) dira la...

Ez da beste agerraldirik.

Burgosko Dotrinan ere andiusteen irakurtzen dugu: Aren andiusteen ta arrotasunen ajolezteaz... (41), baina Mendiburuk Loiolakoan ere hala idatzi zuen. $O E H$-n esaten denez, lehenengo aldiz Larramendirengan aurkitzen da :

handiuste. (AN-erro, B ap. A (andi-uste ; Añ). “Empleado sólo por autores meridionales; se documenta por primera vez en textos de Larramendi, quien, sin embargo, no lo incluye en su diccionario. Soberbia ; vanidad".

HH-n : 'Vanidad, soverbia' a udiá, va nida dea.

'Sobervia, es voz Bascongada (...)'. 'Sobervio', soberbioso, soberbioa, soberbiatsua, goitia, urgullutsua, a ntustetia, antusteduna.

Euskara-Gaztelania hiztegian goitustea soilik aurkitu dugu : goitustea, 'altaneria, soberbia, presuncion'.

baster A: zoco B (2)

... baita nai duten baster / zoco eta ezcutuetan bacarric...

Agerraldi bakarrak.

HH-n : 'Rincon', zocoa, chocoa, bazterra.

violencia, eta fuerza gabe A: borchaz B (2)

... cergatican ori bear dute esan, iñoren violencia, eta fuerza gabe / borchaz.

Agerraldi bakarra du borcha hitzak. Esaldi honen aurretik ere badarabil egileak violencia eta ez da zuzendu : ...eta modu gaiztoequin eta violencia eta enga ñu oec.

Beste behin ageri da bederatzigarren eskuizkribuan. Ondoko hitza, fuerza, beste lau aldiz ageri da baina beti eguin aditzaz : cergatican fuerza eguin ziozten Religioan sartuceco (2) ; ta fuerza eguin bere genijoari (5).

HH-n : 'Violencia', borchá, erchá, erchacuntza, queisua. 'Violentamente' borchaz, queisuaz. 'Fuerza', berriz, 'es voz Bascongada. Viene de el antiguo forza (...)' dio.

Borcha ez da Burgosko Dotrinan ageri.

demporaz A: mugonez B (2)

... eta gueiago a raco Seme eren Gurasoai demporaz / mugonez a visua u emaiten ez diotenac.

B-k egin duen aldaketa honen ondotik, eskuizkribu berean A-k ere demporaz 
hitzaren gainean mugonez idatzi du : Umeai demporaz / mugonez ez emaitea...

Hitz honek, mugonez, bi agerraldi hauek besterik ez ditu.

HH-n : 'A buen tiempo', mugonez. 'A mal tiempo', mugaitzez. 'A tiempo', sin tiempo, fuera de tiempo', mugonez, mugaitzez, mugonean, mugaitzean, eraz, erazaque.

'A buena hora, à mala hora viene, mugonean, mugonez dator, mugaitzean, mugaitzez da tor, ordu ga istoan, donguean, da tor.

Euskara-Gaztelania hiztegian : Mugoan, 'ocasion oportuna, buena'. Mugonez, 'a tiempo, temprano'. Mugon da ora indic, 'todavia hai tiempo, es temprano'.

Hitz hau ez dut Larramendiren idatzietan aurkitu, ez eta Burgosko Dotrinan ere. Kardaberazek badarabil : Echeco ga uzac Testa mentua mugonez eguiñaz (S.I.Ejer. III 228); ta aurrera auzocoac a parte bialdu mugonez, edo eraman (S.I.Ejer. III 362) ; gabaz mugonez bere aurchoac oiera zucendu, (S.I.Ejer. III 376). Otxoa Arinek, berriz, muga onean dio.

desesperatu eraiten dide A: burutic jausi eraguiten didee B (1) ${ }^{59}$

... aen gaiztoac, eta (orren) errebesatuac, ze desesperatu eraiten dide / burutic ja usi eraguiten didee. (Ik. dide : didee aditzaren atalean) ditu.

Desesperacioac (4 eskuiz.) eta desesperacijoco (9 eskuiz.) formak ere erabiltzen

HH-n : 'Perder el juicio, salir de juicio', burutic ja uci.

Euskara-Gaztelania hiztegian ere jauci, 'caer, trastornar-se' eta Jautsi, 'bajar, descender'. HH-n : 'Caer', erori, ja uci, ja utsi.

Burgosko dotrinan ez da esamolde hau ageri baina bai jauzten : peca tu eriozcoan ja uzten dan gucia n... (36). Mendiburuk Loiolakoan, ordea, erortzen idatzi zuen.

A-k ja usi ere badarabil hiru aldiz eta jausiaz, ja usico eta ja usten behin. Lehen eskuizkribuan eroitu-z ordezkatu du bi aldiz. Biak elkarturik ere idatzi ditu : ja usi, edo eroitu; eroituaz, edo ja usiaz. Ohartu-ren sinonimotzat ere erabiltzen du. Esan behar da, hala ere, erori ja usi baino gehiagotan ageri dela eta eroicen-ek erorcenek baino lau agerraldi gehiago dituela. (Ikus eraguin, bestalde, morfologiako tristura ric ez emaiteaga tican : da mu eraguiteag[a tic] sarreran).

eldutasun A: centzunez B (1)

Juramentu eguiten dezunean eguin dezazula eguiaz, justiciaz, eldutasun... / centzunez, ...

Ondotik :

eldutasunarequin, eta juicioarequin A: centzunaz moduz B (1)

A-k ez du centzuna hitza erabiltzen eta elduta sun-ek bi agerraldi horiek ditu.

$H H$-n : 'Sentido, potencia de percibir', bidadia, centzua, centzuna. Burgosko dotrinan Goputza ren centzuac, edo bidadiac (42) ageri da. Mendiburuk Loiolakoan, berriz, Gorputzeco sentiduac jarri zuen.

59 - desespera tu [bakarrik dago ezabatua. B-k orriaren ertzean idatzi du]. 
HH-n : 'Juicio, facultad intelectual', centzua, juicioa, eca doya.

Euskara-Gaztela nia hiztegian : Centzua, 'cordura, seso, prudencia'.

emparaduen A: besteen B (2)

... edo onducerren Semecho ura haciendan, izanagatican ere legueaz contra, eta emparaduen / besteen caltean.

Larramendik HH-n emparagua dio : 'Residuo, sobra', condoa, condarra, emparagua, ondaquina, erresa, ondarra, cutsua.

OEH-n : enparau (V-gip ; Mg PabVoc, Añ, Dv (V), H, A), enparadu (A, que cita a Añ), enpairu (V-ger), enpaidu, enpadu, enparagu (Lar, H). “Documentado desde el s. XIX en autores vizcaínos, en el XX tbn. se encuentra en algunos textos guipuzcoanos. La forma más general es enpara u (...) ; hay enparadu en Añibarro, Astarloa, Arrese Beitia (AmaE 46) y Otxolua (35) (...)".

Enparau, enparadu (Añ), enparagu (Lar, Añ), enpaidu (Pl.). Hemen ez da, ordea, 'Restos, reliquias ; sobras' edo 'residuo' adieran ageri. "Refiriéndose a personas, el prójimo (...)", berriz, V-gip. hizkeran kokatzen da.

Larramendiren Euskara-Gaztela nia hiztegiak ez dakar eta Burgosko Dotrinan ere ez da ageri.

erremedio emon $\mathrm{A}$ : bide, zucenbide artu B (1),

... ze erremedio emongo (emonen $)^{60}$ digu.

Orriaren ertzean B-k : cer bide, cer zucenbide artuco degu.

... ze medio, ze diligencia eguin izan dezu?

Alboan B-k : eta cer zucembide jarri du.

Lehenengo eskuizkribu honetan beste bi aldiz egin du B-k aldaketa bera : erremedioric / bideric. (Ikus estadua sarrera ere). Bestalde, $<\mathrm{r}>$ dela eta, ez dugu Otxoa Arinen eta Irazuztaren dotrinetan aurkitzen dugun remedio formarik, beti erremedioa (5 aldiz), erremedioaraco (1), erremedioaren (1), erremediorican (2) idazten du (ik. erreparatu ere).

Bigarren eskuizkribuan egileak berak aldatu du honela :

medio (efini) : sucenbide (artu),

Efinten dezuz medioren bazuec Jaungoicoaren bildur santua, zere Familiaren biozetan sartuceco ?/ Artucen dituzu ${ }^{61}$ sucenbideren bazuec orreta raco ?

Beste hiru agerraldi ditu zucenbide hitzak eta guztiak egileak berak idatzi ditu testu barruan. Hirugarren eskuizkribuan ere, bigarrenean bezala, $\langle\mathrm{s}\rangle \mathrm{z}$ irakurtzen dugu (ik. honetaz grafia atalean) :

onetaraco sacramentu alta raco orretan Munduaren azqueneraño guelditu izan zizaizcon : onetaraco milla modutara sucenbideac ematen diazcu.

Beste bi agerraldiak 6. eta 9. sermoietan aurkitzen ditugu :

... cergatican asco ta asco joan oi dira confesalecura, ez eren becatuac

60 - emongo [gainean zuzentzen da :] emonen [Lerro batzuk beherago zuzenketa bera ageri da : esango /esa nen]. 61 - Egileak orriaren ertzean egin duen zuzenketa honetan ere lehenik dezuz idatzi du. 
confesacera, (baicic) beren conciencia consultacera, ta zucenbideren bat escacera (6) ; Ez dago, ta ez da izan (becatu mortala eguin duenaren) salvacioraco beste zucenbideric (9).

HH-n : 'Medio, corte, traza', bidea, gozartea, zucembidea.

'Dar algun corte', bideren bat artu.

'Tomar estado', zucembidea, bicibidea, bicimodua artu.

Burgosko Dotrinan ere erremedio ageri da (28) : Cer oscai, edo erremedio. Loiolakoan ez da oscai ageri, geroztik erantsia da. OEH-n ere : oskai (Lar, Añ. H). 'Documentado en CatBurg y en textos meridionales de los ss. XIX y XX'.

erreparatu A: oartu B (1).

Lerro batzuk beherago ere birritan aldaketa bera egin du B-k. Bestalde, A-k ez du inon reparatu esaten (Otxoa Arinek : reparatu bage 148), errepacen (1), erreparaceco (1), erreparacen (1), erreparua (2) baizik. Oartu A-k ez darabil, hiru agerraldiak B-k idatzi ditu.

HH-n : 'Reparar, observar', oartu, arreta tu, arreta eman.

OEH-n : (V-gip.), errepatu (AN-larr), erra patu (G-nav), errepa u (V-gip.). 'Observar, percatarse, (...). Documentado en autores meridionales'.

esaqueriequin A: erausiacgatic B (1)

Besteen culpa, eta gaiztoqueriac pagatu bear ditu ${ }^{62}$ Jesuchristoc zere $\mathrm{mi}^{63}$ lotsagabe ${ }^{64}$ orren esaqueriequin / erausiacgatic

Agerraldi bakarrak.

HH-n : 'Habladuría', era usia, hitzontziqueria, berritsuqueria.

escogiceco A: autatzeco B (2).

... arceco eta escogiceco / a utatzeco escua, eta libertadea.

Agerraldi bakarra du a utatu hitzak, B-k idatzia, hain zuzen. Egileak, berriz, escogitu darabil (escogicen, escogituac). Lehenengo eskuizkribuan ere ageri da baina B-k ez du zuzendu : ... nere Aita S.n Ign. gloriosoaren Seme escogituac. Beste agerraldiak 9. eskuizkribuan dira.

HH-n : 'Escoger', a utetsi, a uta tu, iracurri, bereistu.

escusa A: aitzaquia B (1).

Hamar aldiz darabil escusa egileak : zazpi lehenengoan eta besteak 2., 6. eta 8. eskuizkribuetan. B-k lehenengo bi agerraldiak zuzendu ditu. Aitza quia hitzak ez du beste agerraldirik.

HH-n : 'Escusa', aitzaquia, a chaquia, escusa.

estadu A: egoitza B (1)

... becatu mortalezco estadu / egoitza negargarrizcoan.

62 - ditu [azken irakurketa. Gainean zuzentzen da eta lehen idazketa ez da garbia] 63 - culpac... min [-c eta $-n$ ezabatuta daude :] culpa ... mi. [Ik. min : mi bustidura atalean] 64 - lotsa gabe [azken irakuketa. Lehenik :] losagabe. [Sermoiaren amaieran "lotsa-" idazten du]. 
B-k hurrengo bi agerraldiak ere zuzendu ditu. Lehenengo sermoi honetan, ondotik beste bi aldiz darabil hitz hau testuinguru berean eta ez da ordezkatu :

...eduqui izan du urte ascoan becatu mortalezco estaduan.

2., 8. eta 9. sermoietan ere honela irakurtzen dugu :

... aurquicen dirade oec guzzioc becatu mortalezco estaduan (2);

... estadu nega rgarrijan aurquicen bazera ere (8);

... zein estadu miserablean egon izan dan (8)

Ba ña ô becatuaren estadu negargarrizcoa (8);

Noiz a rtean ira ungo dezu estadu nega rgarrizco ?(9).

HH-n : 'Estado', egoitza, heiña.

estadua A: bicimodua B (2)

Bigarren ez dute obedituceco obligaciorican estaduaren gañeco puntuan.

B-k edo bicimodua jarri du.

Honen ondotik, beste behin ageri da aldaketa bera baina oraingoan egileak berak egin du honela : estadua / bizimodua arceco eta escogiceco ( : B a uta tzeco) escua.

Beste bi aldiz ageri da bizimodua hitza, biak hirugarren eskuizkribuan :

lengo bizimodu becatuzcora ${ }^{65}$

Nai dezute a urrera eraman bizimodu argal becatuzco ori?

Ohar bedi A-k $<$ z> z idazten duela hitz hau.

HH-n : 'Estado, condicion, modo de vivir', bicibidea , bicimodua .

estadua A : zucenbidea

...Umeai demporaz ez emaitea, conveni zaizten estadua / dagocan zucenbidea. ${ }^{66}$ Esta $u$ hitza maiz darabil egileak. (Ikus erremedio sarrera).

genio A : etorquia B $(1,2)$.

Lehen eta bigarren eskuizkribuetan honela zuzendu du B-k :

ezin erremedia tu nezaque, ezin det nere geniorequin / etorquia requin gueiago ; Da becatua, Umeac esconcen dituztenean, bacarric beguiracea haziendara, edo dotera, eta ez Escongueiaren Arimara, eta geniora / etorquira.

Egileak berak ere etorqui badarabil, natural hitzaren ordainetan nahiz genio hitzaren alboan 2., 3. eta 6. eskuizkribuetan :

Aita Cergatican diran natural / etorqui gaiztocoac (2)

...eguiten dute guchienean (ere) beca tu venia la a raco genio ta etorqui curiosoa (6).

Lendabicico (graciaren) excelencia, eta etorqui zerucoa da a rimatic ondacea becatu eriozcoa (3)

HH-n : 'Genio', manua, ancia, ancea, etorquia.

'Natural, substantivo, genio, indole, manua, ancia, ecarraya.

65 - bizimodura [idatzi du lehenik. -ra ezabatu du :] bizimodu

66 - ...Umeai demporaz estadua ez emaitea [idatzi zuen lehenik egileak. B-k orriaren ertzean idatzi du. Lehen idazketa honen ondotik, egileak demporaz hitza mugonez ordeztu du. Ikus hitz honen sarrera]. 


\section{ingratitudez A: esquergabez B (2)}

...eta ingratitudez/esquergabez beterico Seme...

B-k idatzi duen esquergabez hitzak agerraldi bakarra du, egileak beti erdal ordaina baitarabil. Bigarren sermoi honetako agerraldi hau izan ezik, beste guztiak 8. eta 9 . eskuizkribuetan ageri dira : ingratitudera, ingratitudez, ingra to a .

HH-n : 'Ingratitud',esquerguea, esquerbeltza, esquerbaguea, esquerbagueta suna .

'Ingrato', esquerguea, esquerbaguea .

iza eguiten dizutela co A: ciricatzen zaituztelaco B (1)

... eta besteac iza eguiten dizutela co...

B-k eguiten dizutelaco ezabatu eta orriaren ertzean ta ciricatzen zaituztelaco idatzi du.

Ciricatzen : agerraldi bakarra.

HH-n : 'Estimular', ciacatu, ciricatu.

'Provocar, incitar, estimular', a haica tu, a ta ica tu.

justoaren $\mathrm{A}$ : edo bide danaren $\mathrm{B}(1)$

... juramentuac izan bear duela gauza justoa ren gañean.

B-k orriaren ertzean edo bide danaren jarri du.

Beheko aldaketan ere legadu-ren ordainetan ez du hitz bakar bat hautatu : ma nda edo aguindu. Mendibururen dotrinan ere antzeko aldaketak edo eransketak egin ditu Larramendik. Mendib. Justicia : Lar. Edo ecadoya (42) ; Mendib. Senda galla : Lar. Fortaleza edo (42); Mendb. Goguiroa : Lar. Templanza edo (42).

$H H$-n: 'Justo, justa, conforme a justicia', bidezcoa, bidedana, eca doyarra.

casurican batere eguin A: a jola B (2) ${ }^{67}$

... eren gurasoai ezauera ucacen diotenac, casurican batere eguin / ajola gabe ez eren Gurasoai zor dioten a modio, eta errespetoaren...

Agerraldi bakarra du a jola hitzak (Ik. goiko a tencio : arreta). Larramendik bere idatzietan ere badarabil eta birritan, gainera, ardura hitzaren alboan Azkoitiko Sermoian :

Ez nuque nai iñor a jola ta ardura bague onetan erori litequean

... a sco ta asco dira emen a jola ta ardura bagueac,

Goiko a tencio sarreran esan dugunez, A-k cuidadu hitza arretaz ez ezik arduraz ere ordeztu du.

Burgosko dotrinan ajolacabez (33) eta a jolezteaz (41) formak ageri dira.

contentuz A: pozic B (1)

Eta orrequin contentuz/pozic guelditu izan zarade.

Contentacen (1), contentaturican (1) eta contenturic (2) formak ere erabiltzen ditu. Zernahi gisaz, pozic ere badarabil 4 aldiz : birritan bigarren eskuizkibuan eta 
agerraldi bana 7. eta 8.etan. Pozaren pozez ere esaten du 8. eskuizkribuan.

HH-n : 'Contento', gozo, contentamiento, vease alegria, naiquida.

'Alegremente', a legueraró, pozic.

costumbre A: oitura B (1)

Orri berean B-k bost aldiz aldatu du. Orotara, hamar, aurreko sarrerakoa ez ezik beste honako forma hauek ere aldatu ditu : costumbreric : oituraric ; costumbre det: oitua nago; costumbrean : oituran.

Costumbre hitza usu darabil A-k, 43 aldiz. Costumbrea : birritan eta behin costumbreac, costumbrean, costumbreetan, costumbreric eta costumbrerican. "Ohitura" ere erabiltzen du, baina erdarazko ordainak dituen agerraldien alboan gutxi, 12 aldiz bakarrik. Beti <y> z idazten du (oytu, oytuac, oytura, oyturic. Ik. goian $\langle y\rangle$ grafiari buruzkoak) : lehenengo bi eskuizkibuetan hiru aldiz costumbre hitzaren gainean eta testu barruan zortzi bider ageri da 3. 8. eta 9. eskuizkribuetan. Ondoko aldaketa ere A-k egin du : acostumbraturicg : oyturic

Larramendik $H H$-n nahiz bestelako idatzietan $<\mathrm{i}>\mathrm{z}$ idazten $\mathrm{du}$ :

'Costumbre', esta voz, y la Francesa coutume, viene de el Bascuence costuma, que significa lo mismo, bezoa, oitura, oicuna, a stura, costuma, costumbrea, plegua .

'Acostumbrado', oitua, a ciá, usa tua.

Burgosko Dotrina n oitu soilik ageri da (oitu 3, oitutzea 28).

legadu A: manda edo aguindu B (2)

Oi dira beste Seme, eta Senideren bazuec, testamentuan legaduren / bazuequin herencia guchitu ez dezaquien bildurrez,

B-k orriaren ertzean : manda edo aguinduren. ${ }^{68}$

Ma nda hitzak agerraldi bakar hau du.

HH-n : 'Manda, legado' : aguindua, doailla .

mortala A : eriozcoa B (2)

...eguiten dute becatu mortala /eriozcoa, lendabicico a raco...

Hirugarren, laugarren eta seigarren eskuizkribuetan egileak berak darabil hitz hau, eriozcoa, ${ }^{69}$ testuinguru berean, behin eriozco becatua ere esaten duelarik. Nolanahi ere, morta la hitzak agerraldi gehiago ditu.

Burgosko Dotrinan eriotzcoa ${ }^{70}$ ageri da (36), baina Mendiburuk Loiolakoan morta la, edo heriozcoa idatzi zuen eta ondotik morta la ezabatu Larramendik. Beste pasarte batean ere Mendiburuk "Noiz dira mortalac ?" (39) idatzi ondoren, Larramendik ezabatu eta heriotzcoac ipini zuen. Orobat, "pecatu morta la" (36) : Lar. heriozcoa.

HH-n honela idatzi zuen : eriozcoa, eriotsua ('Mortal, que causa muerte').

68 - Aguinderen [idatzi du baina hutsa izaki guk zuzendu dugu :] aguinduren 69 - Azken eskuizkribuetan <tz> z : eriotzco, eriotzcoa... (cf. 4).

70 - Grafia dela eta, eriozcoa (35) ere aurkitu dugu. 
murmuracen A: gaizquiesaca B (1)

... eguiten badezu juramentu murmuracen dezun gauzaren ga ñean...

B-k murmuracen dezun gauzaren gañean ezabatu eta gaizquiesaca zaudenean jarri du.

A-k gaizqui esaqueta darabil :

... murmuracio, ta gaizqui esaqueta da $n$ bezela...(6)

... eta juramentu guilleac, eta gaizqui esaqueta guilleac (4)

HH-n : 'Murmuracion', gaizquiesaca, belchitea, murmuratzea, a la mena, juzcua.

'Murmurar contra alguno', ga izqui esan, belchitu, murmuratu, a la mendu, ja inguin.

necesidadearequin $\mathrm{A}$ : premiaz $\mathrm{B}(1,2)$

Agerraldi kopurua parekoa da : 18 aldiz ageri da necesida de hitza eta bat gutxiago premia (premiña, premija).

Lehen eskuizkribuan necesida de hiru aldiz irakurtzen dugu eta hirurak B-k aldatu ditu : premia z birritan eta behin premia requin. Bigarrenean, 9 agerraldi ditu premia hitzak eta bakarra da B-k erantsia (premian) ; beste guztiak egileak berak idatzi ditu, hauetatik zazpi necesida de (necesida dean, necesida deetan) hitzaren ordainetan eta bestea alboan erantsia (premiazcoac ez diranean).

Premiña eta premija formak ere ageri dira 3., 4. eta 6. eskuizkribuetan. Guztiak egileak berak idatzi ditu testu barruan. Hala ere, hiru aldiz dakusagu necesidade hitzaren alboan :

necesidade, eta premiña guztizco (4.ean); necesa rijoa, ta premiñazcoa (birritan 6.ean).

Necesidade (necesidadea, necesidaderic) hitza ordezkatu gabe, berriz, sei aldiz ageri da zortzigarren eskuizkribuan.

Burgosko Dotrinan premia (29, premiaric 28) irakurtzen dugu, eta ez necesidade.

negargarrizcoan $\mathrm{A}$ : icaragarrian $B(1)$

... becatu mortalezco estadu (egoitza) negargarrizcoan / icaragarrian. (Ikus estadu sarrera)

Negargarrizco, beste hamahiru aldiz darabil : negargarrizcoa, negargarrizcoan, negargarrizcoau, negargarrizcoen, negargarrizcoren, negargarrizcotic. Hemen adibide batzuk :

...eta Aurrac onegatican izqueta negargarrizcoa icasi zuen. (2)

Baña ô becatuaren estadu negargarrizcoa! (8)

...beguira becatuan ez erorceaz, guztiez gañetico zori gaizto negargarrizcoren bat guerta tu ez daquizuten (3)

Icaragarri eta icaragarrizco ere badarabil : Ô guertace zori gaiztocoa, eta guztiz ica ragarria! (6. eskuiz.)

negocio A: beargai B (1)

Bearga $i$ hitza usu darabil A-k eta oficio hitzaren alboan ere ematen du :

... gorpuzean arimeac eguiten ditua n oficio, eta beargaijac. (3) 
... eta beste beargai piedadezcoetan... (3)

... zein besteric guere oytura, eta guere beargaijac. (3)

Gauzac hitzaren ordainetan ere badarabil hirugarren eskuizkribuan. Beste hiru aldiz, accio, ta beargai dio. Bearga $i$ eta bearguiñ ez ezik, bearguinza ere erabiltzen du lau aldiz (bearguincetan, bearguinza, bearguinzaren, bearguinzaz). Bigarren eskuizkribuan industriaz : bearguinzaz aldatu du :

eta eren industriaz / bearguinzaz, eta abilidadez oguia irabazten dutenac.

Negocio, berriz, beste bi aldiz darabil :

... bicicen dirala negocio onetan (2)

... munduco negocio, ta a tseguineta ra entrega turic (8)

HH-n : 'Negocio', en general, bea rquia, bea rga ya, eguitecoa, a boria, eguimbidea . Bere idazlanetan ere maiz erabiltzen du (AS, Cor. etab).

Azkuek horren aldaera den beargei dakar.

DRAEk 'oficio' eta 'labor, asunto, negocio' itzultzen du bietan Larramendiren hiztegian oinarriturik eta Kardaberaz, Arrue, Mendiburu eta Gerrikoren adibideak eransten ditu.

Muniberen El Borracho Burladon (1764) ere ageri da (15) baina eskuizkribu hauetan diren agerraldiak lehenagokoak ditugu.

pachorra A: guibel B.

Hiru aldiz ageri da pa chorra eta guztiak lehen eskuizkribuan. B-k lehen agerraldia soilik zuzendu du. Guibel hitzak ez du beste agerraldirik.

$H H$-n : Pachorra, es voz Bascongada, y se compone de batzi, y de orra, y significa libre, y libertad de inquietudes, batzia ininquetud, y orra libre : y de bachorra se dixo pachorra por la mutacion frequente de la $b$, en $p$.

'Es de valiente pachorra', guibel andicoa da, pachorra ederrecoa.

porfiaca A: (l)eyaca B (1) $)^{71}$

Lehen eskuizkribu honetan A-k beste behin darabil porfia :

...guerra eta porfia oriec eztira la becatu astunac,...

Ez du beste agerraldirik. Leyaca ere ez da beste inon ageri.

HH-n : Porfia, viene del Bascuence burfidia, que significa lo mismo, y viene de buru fidia, demasiada confianza de si mismo, ò en su cabeza, y es de donde vienen las porfias. Burfidia, porfia, setá, leya, sepá, hisia . 'Porfiar', burfidia tu, porfiatu, leyatu.

prometicen A: aguintzen B (1)

Lehen eskuizkribuan hiru aldiz aldatu du B-k : birritan forma hau bera eta beste behin prometiceagatica $n$ ezabatu eta lerro artean aguintzea idatzi du. Nolanahi ere, "agintzeagatik" irakurri behar da.

Aguindu ere erabiltzen du A-k (aguindua, aguincen, aguinduagatican, aguinduan, aguinduaren, aguinduic, aguinduricoac) baina gehienetan 'ordenar,

71 - B-k bazterrean eyaca idatzi du. 
mandar' (Larramendik dakarren moduan) adieran :

eztet eguingo Aitac a guincen didana (1)

aguindu zion Medicuac confesa cedila (3)

Ugazabac aguincen dizutenean, (2)

HH-n, 'Prometer', a guindu, promestu, luscandu, loscaindu.

Burgosko Dotrinan ere ageri da aguindu, baina Mendiburuk Loiolakoan lehenik esqueiñiric (10) idatzi zuen eta Larramendik ezabatu eta a guindua-z ordezkatu.

\section{respetoa $\mathrm{A}$ : beguirunea $\mathrm{B}$.}

Lau aldiz darabil respetoa : guztiak lehenenego bi eskuizkribuetan. Bigarren eskuizkribuko lehen agerraldia zuzendu du B-k. Errespetoa (errespetoaren) ere birritan darabil eta biak ere lehen bi eskuizkribuetan. (Ik. erreparatu sarrera).

Larramendik errespeto a ere badakar HH-n : 'Respeto', errespeto a , beguirunea , bea curta . sucedicen A: guertatzen B (1)

Suceditu (sucedicen) lau aldiz erabiltzen du lehen eskuizkribuan. Ez da beste inon ageri. B-k lehen agerraldia bakarrik zuzendu du.

Guertatu ere badarabil A-k (guertacen, guertatce, guertatuco) hirugarren eta laugarren eskuizkribuetan baina agerraldi gehienak azken eskuizkribuetan dira.

sustrai- A : cutsu- B (1)

... ez oi zaizu faltatu (...), ez eta intencioa ren sustrairem bat ere

B-k sustrairem ezabatu eta cutsuren jarri du. Ez da beste agerraldirik.

Burgosko Dotrinan ere "arrasto" (38) adieran ageri da, baina Mendiburuk Loiolakoan siñaleac idatzi zuen eta Larramendik ezabatu eta cutsuac ipini.

Egileak berak ere egin ditu hainbat aldaketa (intimacen : zemacen; Islan: ugaldean ; pesadunbreaquin : asacabaz; temachoac : muquerqueriachoac ${ }^{72}$; guardia : zaindunac etab.) eta goian zerrendatu ditugunen artean esan behar da gogo, arreta, pozic, oytura, zucenbide / sucenbide, bizimodu, etorqui, eriozcoa, premia, beargai eta guertatu ere erabiltzen dituela, baina ez dira aurkeztu ditugun sarreren erdira ere iristen. Areago, honen guztiaren ondoren, andiuste hitza lehendabizikoz Larramendik erabili zuela jakiteak frogarik bortitzenetakoa genuke bere egiletasunaren aurka. Beste hainbat sarrerek ere, ohartzeko aukera eskaini dugunez, Hiztegi Hirukoitza ren argazkia dirudite : amenazar (amenazatu)meachatú ; antojo (antoxu)-guraria ; arca-cuchá ; reparar (erreparatu)-oartu ; escoger (escogitu)-autatu ; escusa-aitzaquia ; estado (estadu)-egoitza ; ingratitudesquerbaguea ; justo-bidedana ; legado(legadu)-aguindua ; murmurar (murmuratu)gaizqui esan ; pachorra-guibel ; porfiar-leyatu ; prometer (prometitu)-aguindu ; respeto(respetoa, errespetoa)-beguirunea ; vanidad-andiuste ; violencia-borcha.

72 - OEH-n : mukerkeria : (H (+ -kh-). 1. Dureté de manières, de langage. [...] Maussaderie, air, mine sombres, mornes, mécontents. [...]. 2. Indocilité, insoumission, résistance $\mathrm{H}$ (que cita los ejs. de Astarloa). Orien mukerkeri ta aldart ga istoac me-meki arzea. Mb IArg I 304. Humeen mukerkeriz ta esker gistoz. Ib. 233. Eztira bada gastiak euren okerkerija, mukerkerija eta gesta kerijeta rako. Astar II 93. [Semiek] egiten dabeela eurak [gurauak] a ginduten deutzena, erremuskada eta mukerkerija baga. Ib. 77. Bv AsL 29. Alz Ram 54. Zait Plat 35 (v. tbn. Sof 189). v. tbn. Arr CDoc 133.

Azkuek mukerta sun dakar. Esquivez (Mog. PAb 60). Carácter soberbio, arrogante (G-and, S.P.). Resistencia (Bc, ..., Ur MarIl). OEH-n : (V, G, AN ap. A; VocCB -> Dv, H (+ -kh-), Zam Voc). 


\section{Azken hitzak}

Atal bakoitzean Larramendiren egiletasunaren aurka aurkitu ditugun frogak batzean, ez baitugu uste bakoitzak bere aldetik hori erabakitzen duenik, izenburura jo behar dugu eta berretsi eskuizkribu hauek Larramendi ez den XVIII. mendeko autore ezezagun batek idatzi zituela. Ez da dena ukatzea, ordea, baieztatzeko moduan baikaude B letraz izendatu dugun zuzentzailea Larramendi bera dela, oraingo honetan ere maisu lanak egiten ez ezik bere maisutza agerian utziz. Lehenengo ataletan frogatuta geratu dela uste dugu, eskua bera ahaztu gabe, baina azkenengoan are argiago lehenengo aldiz Larramendik erabili zuen andiuste hitza, $O E H$-n biltzen denez, eskuizkribu hauetan B-k idatzi duelako, hain zuzen ere, eta ez testuaren egileak. Zernahi gisaz, A-k erabili balu ere ez luke gure ondorioa lurreratuko bestela ere aski froga baditugulako, baina eskuizkribu hauek ezezagunak izaki eta Larramendiren hiztegia argitaratu baino lehenagokoak direla kontuan hartuz, hitz honen agerraldia aurreratu beharrean aurkituko ginateke. Ez da horrela, ordea, eta ausartuko ginateke esatera, gainera, agian Larramendik hemen erabili zuela hitz hau lehenengo aldiz. Nolanahi ere den, Larramendiren lekukotasun honek eskuizkribu hauek XVIII. mendekoak direla ere frogatzen dute.

Gutun-azalean Larramendiren izena agertzeak, bada, izan du bere emaitza eta bazuen bere lotura baina argi geratu da, bestalde, izenpetu eta datatu gabeko eskuizkribuetan zuhurtziaz eta tentuz ibiltzea komeni dela. Hala biz. •

\section{Aipamenak}

- Altuna, P., 1967, "Larramendi'ren iztegi berria", Euskera 2. aldia XII, 139-300.

- Altuna, P., 1982, Mendibururen idazlan argitaragabeak. Edizio kritikoa, 2 lib., "Euskararen Lekukoak" Saila, Euskaltzaindia, Bilbo.

- Altuna, P., 1984, “La auténtica biblioteca de Larramendi", Muga 228, 66-81.

- Altuna, P., 1992, "Ochoa de Arin-en Doctrina Christiana-ren (1713) hizkeraren laburpena", Euskera 37. liburukia (2. aldia), 573-589.

- Altuna, P. \& Lakarra, J.A (arg.), 1990, Manuel Larramendi. Euskal Testuak, Andoain.

- Altzibar, X., 1991, "Kardaberazen bizkaierazko dotrina : 1783ko edizioa", in Lakarra \& Ruiz Arzalluz, I., (arg.), 259-276.

- Altzibar, X., 1992, "Larramendi eta literatur-gipuzkera", in Lakarra (arg.) 1992a, 325-360.

- Arzadun, Martin de, 1731, Doctrina Christianeen Explicacinoa, Vitoria,

- Arzadun, Martin de, 1758, Doctrina Christianeen Explicacinoa, Iruñea.

- Irazuzta, Juan de, 1739, Doctrina Christiana, Iruñea.

- Kardaberaz, A, 1760, Christavaren bicitza, La Gran Enciclopedia Vasca, Bilbo, 1973, 49-149.

- Kardaberaz, A, 1761, Eusqueraren berri onac, La Gran Enciclopedia Vasca, Bilbo, 1973, 154-170.

- Kardaberaz, A, Egercicioac (I, II, III, IV), La Gran Enciclopedia Vasca, Bilbo, 1973,171-395.

- Kardaberaz, A, Dotrina Cristiana edo Cristiña u Dotrinea, La Gran Enciclopedia Vasca, Bilbo, 1973, 397-455.

- Kardaberaz, A, Christauaren Doctrina, Aita Astetec erdaraz, eta guero Aita Agustin Cardaberacec euscaraz arguitara emana (Donostia), La Gran Enciclopedia Vasca, Bilbo, 1973, 458-478. 
- Kardaberaz, A, 1764, Jesus, Maria, ta Joseren devociñoco Libruchoric a ta ra rico devociño batzuc, La Gran Enciclopedia Vasca, Bilbo, 1974, 51-96.

— Lakarra, J., 1985a, "Larramendiren hiztegigintzaren inguruan", ASJU XIX-1, 9-50.

— Lakarra, J., 1985b, “Literatur gipuzkerarantz : Larramendiren Azkoitiko Sermoia (1737)", ASJU XIX-1, 237-281

— Lakarra, J., 1986, “Burgosko Dotrina (1747) : I. Testua eta oharrak", ASJU XX-2, 533-594.

— Lakarra, J., 1987a, "Burgosko 1747ko Dotrina : II. faksimilea eta hiztegia”, ASJU XXI-1, 277-317.

— Lakarra, J., 1987b, “Oikiako dotrina (1759)”, ASJU XXI-2, 515-564.

- Lakarra, J., 1992a, (arg.) : Manuel de Larramendi. Hirugarren mendeurrena (1690-1990), Andoaingo Udala-Euskaltzaindia-Gipuzkoako Foru Aldundia-Eusko Jaurlaritzako Kultura Saila, Andoain.

— Lakarra, J., 1992b, “Larramendirekin aurreko hiztegigintzaren historiaz : aztergai eta gogoeta", in Lakarra (arg.) 1992a, 279-312.

- Lakarra, J., 1996, Refranes y Sentencias (1596). Ikerketak eta Edizioa. Euskararen Lekukoak-19, Euskaltzaindia, Bilbo.

- Lapesa, R., 1984, Manual de historia de la lengua española, Gredos, Madrid.

- Lariz, Francisco X., 1773, Crista u Dotrinaren Esplicacioa a ur-enzat ta andienzat, Madrid.

- Larramendi, M., 1729, El imposible vencido, y Arte de la Lengua Bascongada, Salamanca.

- Larramendi, M., 1745, Dicciona rio Trilingüe, Donostia.

- Larramendi, M., Corografía de Guipúzcoa, Editorial Amigos del Libro Vasco, 1985.

- Larramendi, M., (ik. Tellechea Idigoras).

- Larramendi, M., Euska ra-Gaztelania hiztegia. (Ik. Altuna 1967).

- Mendiguren, X., 1987, "El Borracho Burladoko euskararen azterketa (1764)", ASJU XXI-1, 135-162.

- Mitxelena, K., 1959, “La obra del P. Manuel de Larramendi (1690-1766)”, SHLV II, 900-912.

- Mitxelena, K., 1977, Fonética Histórica Vasca, 2. arg., Donostia.

- Mitxelena, K., 1978a, "Miscelánea Filológica Vasca I", PT 363-385.

- Mitxelena, K., 1978b, "Para una historia de la ortografía vasca" in "Miscelánea filológica vasca II" [PT 391-395].

- Mitxelena, K., 1979, “Miscelánea Filológica Vasca III”, FLV 32, 213-236. [PT 411433].

— Mitxelena, K., 1983, “Mendiburu eta Larramendi”, Euskera XXVIII [SHLV II, 912915].

- Mitxelena, K., 1987, Pa labras y Textos, EHU, Gasteiz.

- Mitxelena, K., 1988, Sobre Historia de la Lengua Vasca, 2 lib., J.A. Lakarra (arg.), ASJU-ren gehigarriak, 10, Donostia.

- Mitxelena, K. \& Sarasola, I., 1987..., Orotariko Euskal Hiztegia, Euskaltzaindia, Bilbo.[OEH].

- Ochoa de Arin, J., 1713, Doctrina Christia na ren Explicacioa, Pedro de Ugarte-ren Echean, Donostia.

- Ondarra, F, "Zegamako Doctrina Christiana (1741)", ASJU XVIII-2, 1984, 3-62.

- Oyharçabal, B., 1989, "Les travaux de grammaire basque avant Larramendi (1729)". ASJU XXIII-1, 59-73.

- Oyharçabal, B., 2001, "Statut et évolution des lettres basques durant les XVIIème et XVIII ème siècles", Lapurdum VI, 219-287. 
- Segurola, K., 2002, "Jeanne d'Arc pastoralaren eskuizkribua : le plus ancien connu ?", La purdum VII, 313-326.

- Segurola, K., "Paperaren ur markak", ASJUren hurrengo alean argitaratzekotan.

- Segurola, K., “Oikiako Dotrinak. Francisco Antonio Aguirre (Marin 1728 - Oikia 1805)", ASJUn argitaratzekotan.

— Tellechea Idigoras, J. I., 1966, "El Jesuita Manuel de Larramendi”, BAP XXII, 307-360.

- Tellechea Idigoras, J. I., 1968, “Larramendi y Cardaveraz. Censura y réplica inéditas sobre un libro de piedad", ASJU II, 3-31.

- Tellechea Idigoras, J. I., 1973, Au to biografía y otros escritos, Sociedad Guipuzcoana de Ediciones y Publicaciones, Donostia.

- Tellechea Idigoras, J. I., 1983, Sobre los Fueros de Guipúzcoa, Sociedad Guipuzcoana de Ediciones y Publicaciones, Donostia.

- Tellechea Idigoras, J. I., 1990, Escritos Breves, Sociedad Guipuzcoana de Ediciones y Publicaciones, Donostia.

— Urgell, B., 1985, “Literatur bizkaieraz : Añibarroren Esku-liburua”, ASJU XIX-1, 65-118.

- Urgell, B., 1987a, "Esku-liburua ren grafi aldaketak (1802-1821)", ASJUXXI-2, 357-387.

- Urgell, B., 1987b, "Esku-liburua ren hiztegi aldaketak : 1. maileguak", ASJU XXI-3, 683-708.

— Urgell, B., 1992, “Axular eta Larramendi”, in Lakarra (arg.) 1992a, 221-246.

- Urkizu, P., 1992, “XVIII. mendean Larramendiren Hiztegi Hirukoitzak iparraldeko zenbait idazlerengan duen eraginaz", in Lakarra (arg.) 1992a, 313-324.

- Urquijo, Julio de, 1907a, Obras vascongadas del doctor labortano Joannes D'Etcheberri (1712) con una introducción y notas por Julio de Urquijo e Ibarra, Paris. Berrarg. faks. RIEV XXVIII, Bilbo, 1976.

- Urquijo, Julio de, 1907b, "Nota de Bibliografía Vasca I. El Catecismo de Arzadun", RIEV I, 84-89 eta 416-420. 